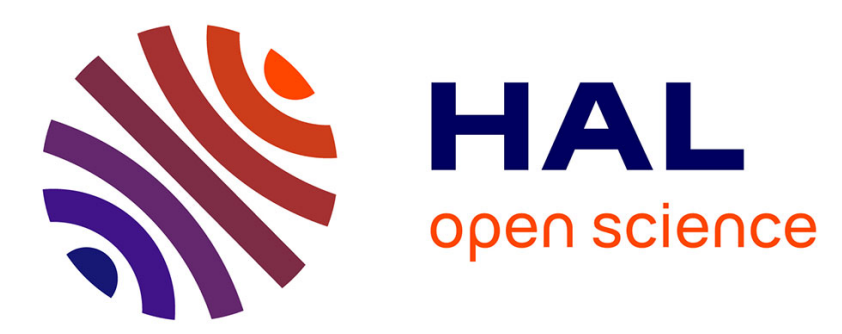

\title{
Sequential extension as a record of Corsica Rotation during Apennines slab roll-back
}

Frédéric Gueydan, Mélody Phillippon, Melanie Noury, Jean-Pierre Brun

\section{To cite this version:}

Frédéric Gueydan, Mélody Phillippon, Melanie Noury, Jean-Pierre Brun. Sequential extension as a record of Corsica Rotation during Apennines slab roll-back. Tectonophysics, 2017, 710-711, pp.149161. 10.1016/j.tecto.2016.12.028 . insu-01424859

\section{HAL Id: insu-01424859 \\ https://hal-insu.archives-ouvertes.fr/insu-01424859}

Submitted on 3 Jan 2017

HAL is a multi-disciplinary open access archive for the deposit and dissemination of scientific research documents, whether they are published or not. The documents may come from teaching and research institutions in France or abroad, or from public or private research centers.
L'archive ouverte pluridisciplinaire HAL, est destinée au dépôt et à la diffusion de documents scientifiques de niveau recherche, publiés ou non, émanant des établissements d'enseignement et de recherche français ou étrangers, des laboratoires publics ou privés. 


\section{Accepted Manuscript}

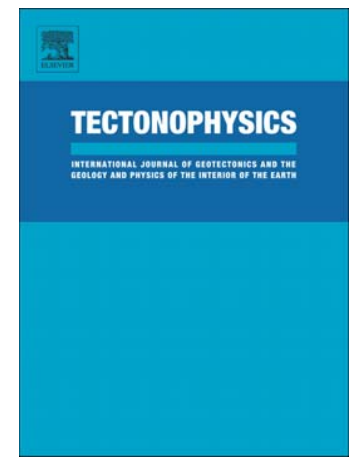

Sequential extension as a record of Corsica Rotation during Apennines slab roll-back

Frédéric Gueydan, Jean-Pierre Brun, Mélody Phillippon, Mélanie Noury

PII:

S0040-1951(16)30658-8

DOI: $\quad$ doi: $10.1016 /$ j.tecto.2016.12.028

Reference: $\quad$ TECTO 127371

To appear in: $\quad$ Tectonophysics

Received date: 16 February 2016

Revised date: $\quad 22$ December 2016

Accepted date: 30 December 2016

Please cite this article as: Gueydan, Frédéric, Brun, Jean-Pierre, Phillippon, Mélody, Noury, Mélanie, Sequential extension as a record of Corsica Rotation during Apennines slab roll-back, Tectonophysics (2016), doi:10.1016/j.tecto.2016.12.028

This is a PDF file of an unedited manuscript that has been accepted for publication. As a service to our customers we are providing this early version of the manuscript. The manuscript will undergo copyediting, typesetting, and review of the resulting proof before it is published in its final form. Please note that during the production process errors may be discovered which could affect the content, and all legal disclaimers that apply to the journal pertain. 


\section{Sequential extension as a record of Corsica Rotation during}

\section{Apennines slab roll-back}

Frédéric Gueydan ${ }^{1}$, Jean-Pierre Brun ${ }^{2}$, Mélody Phillippon ${ }^{3}$ and Mélanie Noury ${ }^{3}$.

1. Geosciences Montpellier UMR 5243 CNRS, Université de Montpellier, 34095 Montpellier cedex 5, France

2. Géosciences Rennes, UMR 6118 CNRS, Université Rennes 1, 35042 Rennes CEDEX, France

3. Geosciences Montpellier UR 5243 CNRS, Université des Antilles, 97159 Pointe à Pitre, French West Indies

\section{Abstract}

The Mediterranean geodynamic system is an exceptional natural laboratory to study the complexities of back-arc extension during subduction rollback. Corsica is a key locality that recorded the Alpine subduction-collision history followed by $30 \mathrm{Ma}$ of the Apennines slab rollback, responsible for the successive opening, from West to East, of the Liguro-Provençal basin and the Tyrrhenian Sea. The overall strain pattern of the Alpine metamorphic units of Alpine Corsica is studied through a synthesis of i) available geological maps, ii) geochronological data and iii) newly acquired structural data relative to successive events of ductile and brittle extension, Three main stages of extension are recorded: 1/ Syn- 
metamorphic Oligocene extension accommodated by $\mathrm{N} 140^{\circ}$ trending ductile shear zones, that correspond to the reactivation of a major Alpine thrust; 2/ Burdigalian ramp-flat extension with $\mathrm{N} 60^{\circ}-70^{\circ}$ trending fault zones that controlled the deposition of onshore piggy-back basins (e.g. St Florent basin), and 3/ Serravalian N-S trending fault zones. From a geodynamical point of view, these successive extensional deformations in Alpine Corsica can be correlated to the history of the Apennines slab rollback. The two first stages are related to a southeastward rollback of the Appennines slab that successively triggered: 1/ Continental rifting in Oligocene leading to the opening of the Liguro-Provençal basin and 2/ Burdigalian extension with $\mathrm{N} 60^{\circ}-70^{\circ}$ trending fault zone, oblique to the Alpine thrust that, after a counterclockwise rotation of the Corso-Sardinian block, became unable to accommodate extension. Finally, the third stage that gave NS-trending fault zones developed in Serravalian, at the onset of Tyrrhenian rifting, related to an eastward rollback of the Apennines slab, as a response of slab tearing in Sicily.

\section{1-Introduction}

The Tertiary geodynamic evolution of the Mediterranean mainly corresponds to the formation of three backarc extensional systems (Alboran, Ligurian-Thyrrenian, AegeanAnatolian) driven by slab rollback (Wortel and Spakmann, 2000; Faccenna et al. 2004). In Central Mediterranean, the rather complex morphology of the Apennines slab is related to 30 Myr of slab rollback responsible for the opening of two major basins: the Liguro-provençal basin and the Tyrrhenian sea (Faccenna et al., 2004). In this framework, Corsica has a key position where the Alpine shortening occurred up to $30 \mathrm{Ma}$ and was followed successively by the Liguro-Provençal extension, from 30 to $20 \mathrm{Ma}$, and the Tyrrhenian extension since $15 \mathrm{Ma}$ (Jolivet et al., 1991; Molli 2008). The aim of the present paper is to analyse, in the Alpine 
metamorphic units of Corsica (called "Alpine Corsica"), the 3D structural pattern that resulted from the successive stages of Cenozoic deformation.

Corsica shared with the Alps a common history from Cretaceous to Oligocene (Gueguen et al., 1998; Faccenna et al., 2004). In the Alps, the Penninic thrust that is defined by the boundary between the metamorphic domain that evolved mainly between 70 and 30 Ma (see synthesis in Rosenbaum and Lister, 2004) and the external non-metamorphosed terranes, is underlined by Eocene flysh deposition (Handy et al., 2010) (Fig. 1). In Alpine Corsica, the metamorphic rocks that mainly consist in oceanic derived rocks, the so-called Schistes Lustrés units (SL), have registered a subduction-exhumation cycle with a metamorphic peak dated between $70 \mathrm{Ma}$ and $35 \mathrm{Ma}$, similar to the Alps (Handy et al., 2010; Malusa et al., 2015) (Fig. 1). The thrust contact between the metamorphic nappe stack and the non-metamorphic external zone (Hercynian basement without sedimentary cover) that is underlined by Priabonian sediments is an equivalent of the Penninic front (Caron et al., 1990; Molli, 2008) (Fig. 2).

Since Oligocene, the Alps underwent collision with westward propagation of the external thrusts and Miocene flexural deposits (Handy et al., 2010) (Fig. 1), while Corsica underwent two major extensional events, related to the rollback of the Apennines slab (see synthesis in Molli, 2008). First, the opening of the Liguro-Provençal ocean isolated the Corso-Sardinian block from the European plate and, consequently, from the Alpine-related deformation. In Southeast France, several onshore basins at $30 \mathrm{Ma}$ (in late Rupelian; Seranne, 1999) mark that Oligocene continental rifting. Subsequent breakup occurs at $21.5 \mathrm{Ma}$ with the formation of the Liguro-Provençal oceanic basin up to $15 \mathrm{Ma}$ (Chamot-Rooke et al., 1999). A counterclockwise $(\mathrm{ccw})$ rotation of around $55^{\circ}$ of the Corso-Sardinian block, between 21.5 and 15 Ma (Edel et al., 2001; Gattacceca et al., 2007; Rehault, 1981), controlled Liguroprovençal opening and seafloor spreading. Second, opening of the Tyrrhenian Sea isolated the 
Corso-Sardinian block from the Apennines/Adria (Gueguen et al., 1998; Chamot-Rooke et al., 1999; Faccenna et al., 2004). Basins belonging to the Tyrrhenian Sea display ages that decrease eastward. The opening of the Bastia and Sardinia basins occurred at $32 \mathrm{Ma}$, attesting for a complex and polycyclic history of basin opening, from Ligurian to Tyrrhenian (Mauffret et al., 1995; 1999) (Fig. 1). The first deposits in the Cornaglia basin are dated at $12 \mathrm{Ma}$ (Chamot-Rooke et al., 1999) (Fig. 1). Rifting started in the Vavilov basin at 7 Ma and breakup and subsequent seafloor spreading occurred at 5-2Ma (Chamot-Rooke et al., 1999) (Fig. 1). At the easternmost tip of the Tyrrhenian Sea, seafloor spreading in the Marsili basin started at $2 \mathrm{Ma}$ and is still active nowadays (Chamot-Rooke et al., 1999) (Fig. 1). This eastward migration of extension recorded the eastward rollback of the Apennines slab (Wortel and Spakman, 2000; Rosenbaum and Lister, 2004; Faccenna et al., 2004). The docking of buoyant continental material to the North and South of the Apennine subduction triggered the tearing of the Apennines slab, which consequently a progressive narrowing of the trench. This event has been responsible for an acceleration of the Apennine slab rollback (Rosenbaum and Lister, 2004).

In Alpine Corsica, the extension-related structures have been mostly attributed to the Ligurian stage of rifting (Jolivet et al., 1998; Molli, 2008 and references therein). More specifically, the onshore deposition of the St Florent basin was considered to occur during the Oligocene in the hanginwall of the East Tenda Shear Zone (ETSZ) coeval with the ductile to brittle-ductile extensional exhumation of the Tenda massif in the footwall (Fournier et al., 1991; Daniel et al., 1996; Jolivet et al., 1998). However, Cavazza et al. (2007), questionned this interpretation by pointing out a $6 \mathrm{Myr}$ gap between cooling ages of the Tenda massif (e.g. age of exhumation/extension 30-25 Ma; Fig 2) and the ages of first infill in the St Florent Basin (19-18 Ma; Fig. 2) (Cavazza et al., 2007). Moreover, Fellin et al. (2006) suggested that the subsidence of the Saint-Florent Basin was not related to detachment faulting along the 
ETSZ. The compilation of low-temperature (LT) thermochronological ages in the metamorphic units of Alpine Corsica (AFT, U-Th-He in Fig. 2 and references in figure caption) shows indeed a cluster of ages ranging between 20 and10 Ma, contemporaneous with basin deposition. The first deposit of St Florent occured after the continental break-up in the Liguro-Provençal basin (at 21.5, Chamot-Rooke et al., 1999), implying a «post-rift » environnement instead of a «syn-rift». The deformation event that triggered rock exhumation, between Ligurian break-up and Thyrrenian rifting, therefore remained to be identified.

In this paper, we first summarize the geological key features of Alpine Corsica. We then present a new tectonic map of Alpine Corsica constrained by i) newly acquired field data (more than 600 structural measurements) and ii) an original synthesis of available geological maps and geochronological data. The main outcome of the study is a characterization of the 3D post-metamorphic deformation pattern, through a detailed mapping of foliation trajectories. We identified three main sets of extensional structures at map-scale and their sequence of development using the sedimentary record from the onshore and offshore Neogene basins. Finally, we interpret the variations of the extension direction in the frame of the Apennines slab rollback and the rotation of Corsica.

\section{2- General structure: Tectonic map of Alpine Corsica}

\section{1/ Major tectonic units: a tectonic log}

Our new structural map of Alpine Corsica is constrained by both (i) a synthesis of data from 11 BRGM geological maps and (ii) data acquired during extensive structural mapping (616 foliation measurements; stereoplot in Fig. 3). The references for the 11 BRGM geological maps are as follows, form North to South and from West to East: Luri (Lahondère 
et al., 1992), St Florent (Rossi et al., 1994a), Bastia (Lahondère, 1983), Santo Pietro Di Tenda (Rossi et al., 2001), Vescovato (Lahondère et al., 1994), Corte (Rossi et al., 1994b), Cervione (Guieu et al., 1994), Venaco (Amaudic du Chaffaut et al., 1985), Pietra di Verde (Caron et al., 1990), Ghissonaccia (Jauzein et al., 1985) and Bastelica (Rossi et al., 2012).

The geological units belonging to Alpine Corsica have been defined on the basis of their lithology/mineralogy (Lahondère, 1996), metamorphic conditions (synthesis in Vitale Brovarone et al., 2013) and structure (Lahondère, 1996; BRGM maps and our newly acquired field data). From these criteria, we define six major tectonic units (Fig. 3) and we propose a unified description of the metamorphic nappes from North (Cap-Corse) to South (Castagniccia) that was missing up to now. The non-metamorphosed Hercynian basement crops out to the West and South of Alpine Corsica (Unit 1; Fig. 3). Strongly deformed Eocene basins (nummulites-bearing flyschs) lay unconformably on the non-metamorphosed basement (Unit 2; Fig. 3). These sediments belong to the foreland Eocene basin deposits. A Hercynian basement unit affected by a medium to high-pressure (M-HP) metamorphism (unit 3: Tenda massif, West of St Florent, "External Continental units" of Molli (2008)- Popolasca, Francardo, Corte, Razzo Bianco) is thrust onto both the non-metamorphosed basement and the Eocene foreland sediments (Unit 3; Fig. 3). This late Eocene thrust is an equivalent of the Alpine Penninic front (Figs. 1 and 2). The basal thrust crops out to the West of Corte where it is cut and reworked by late normal faults (Molli, 2008). Peak metamorphic conditions yield a maximum of $10 \mathrm{~kb}$ (Gueydan et al., 2003; Malosoma et al., 2006; Malasoma and Marroni, 2007). For clarity and simplicity, we refer to these continental metamorphic units as the Tenda unit sensu lato (s.l.) (Fig. 3). They can be interpreted either as the low-pressure (LP) equivalent of the Alpine internal crystalline massifs or as the exhumed deep portion of the external crystalline massifs, structurally located below the Penninic front. 
The Schistes Lustrés s.l. (SL) are thrust on top of both the Eocene foreland basin and metamorphosed basement (Tenda unit s.l.). The SL are mostly made of metamorphosed oceanic units: peridotites, gabbros, basalts and sediments with locally slices of continental fragments (e.g. continent-ocean transition affinity; Vitale-Brovarone et al., 2011) and are affected by a degree of metamorphism decreasing upward. The metamorphic pile can be divided into three main units.

At the base, the Castagniccia unit, consists of meta-sediments: marbles, calcschists, schists, with local intercalations of basalts and gabbros affected by high-pressure lowtemperature (HP-LT) metamorphism (unit 4 regrouping the Brando and Sisco units of Lahondère, 1996; corresponding to the Alpine Schistes Lustrés s.s.; Fig. 3). Estimates of the PT conditions give a maximum pressure of $14-17 \mathrm{~kb}$ and late Cretaceous age of $65 \mathrm{Ma}$ for the peak of metamorphism (Jolivet et al., 1998; Molli, 2008 and discussion in Vitale-Brovarone et al., 2013) (Fig. 2). Above this unit, two oceanic dominated units can be distinguished mainly based on their degree of Alpine metamorphism. The Lower oceanic unit (unit 5 regrouping the Mandriale, Farinole and Morteda units of Lahondère, 1996; Fig. 3) consists of basalts, gabbros and peridotites with slices of eclogitic gneisses. It recorded pressure conditions ranging from 22 to $24 \mathrm{~kb}$, which are the maximum pressure conditions recorded by the entire Alpine nappe stack (Ravna et al., 2010; Vitale-Brovarone et al., 2013). Above this unit, the Upper oceanic unit (unit 6 regrouping the Pigno, Gratera, Centuri, Inzeca, Vecchio, Linguizzetta, Santa Lucia and Balagne units of Lahondère, 1996; Fig. 3) recorded a low to medium pressure (L-MP) metamorphism (maximum $10 \mathrm{~kb}$; Vitale-Brovarone et al., 2013). The Balagne unit is non-metamorphosed and contains obducted oceanic material: serpentinite, gabbros, pillows lavas and oceanic flysch sediments. Santa Lucia and Pigno units consist of continental fragments with L-MP metamorphism (Jolivet et al., 1998). Note that within the Upper oceanic unit, pseudotachylites have been recently discovered in the Gratera units at 
medium pressure (transition from greenschits to blueschists facies in meta-gabbros and peridotites; Austrheim and Andersen, 2004; Andersen and Austrheim, 2006).

Miocene sediments deposited on top of the previously defined units (mainly SL) are found in three onshore basins: Saint Florent, Francardo and Aleria (Unit 7; Fig. 3). Within these basins, the sedimentary record ranges from Burdigalian to Messinian. The Francardo and St Florent basins contain exclusively 20-14 My old deposits (Burdigalian to Langhian; Cavazza et al., 2007; Ferrandini,1999) (Fig 2). The Aleria basin contains Burdigalian to Pliocene sediments with a chance of depocenter location during Langhian (Fig. 3).

\section{2/ Ductile deformation}

The metamorphic units (Tenda s.l. and SL) recorded two events of ductile deformation. First, a top-to-W-SW shearing is observed in HP-LT assemblages, resulting from subduction-related thrusting (Malavieille et al., 1998; Molli, 2008; Fournier et al., 1991; Daniel et al., 1996, Jolivet et al., 1998). The ages of top-to-W-SW shearing are late Cretaceous in SL and Mid-Eocene in Tenda (Fig. 2 with references in caption) (Brunet et al., 2002; synthesis in Vitale-Brovarone et al., 2013). This implies two stages of HP-LT metamorphism and associated deformation. Recent age constraints on SL unit seem to indicate a synchronous sudbuction of the Tenda massif and SL (Vitale Brovarone and Herwartz, 2013). Despite this complexity, the ductile deformation with top-to-W-SW shearing indicates that the contact between the major tectono-metamorphic units presented above are thus major thrusts (Caron, 1994; Lahondère, 1996; Harris 1985; Malavielle et al., 1998; Mattauer et al., 1981; Molli et al., 2006), formed within the subduction zone. The internal structures of these units are complex and commonly show isoclinal folding, typical of thrust related structures. Our study does not concern this syn-metamorphic deformation, but aims at understanding the deformations that occurred at shallower levels, after thrusting and 
subsequent exhumation - i.e. low metamorphic to post-metamorphic deformations. Following thrusting, a second ductile deformation event was recorded with top-to-E shearing synchronous to HP to LP mineral assemblages, suggesting an exhumation-related deformation whose ages are also diachronous, starting in Paleocene in the SL and in late Eocene/Early Oligocene in the Tenda (Brunet et al., 2002) (Fig. 2). Two stages of ductile deformation related to exhumation thus characterize Alpine Corsica. An Eocene ductile exhumation only recorded in the SL with top-to-E shearing and an Oligocene ductile exhumation of the Tenda and also recorded in the SL with also top-to-E shearing.

\section{3/ Foliation trajectories}

The metamorphic foliation of Alpine Corsica is a first order marker of later extensional deformations that occurred since Oligocene, even if some variations in the foliation attitude (i.e. strike and dip) can be related to pre-Oligocene deformations responsible for foliation development. The trajectories of bedding-parallel high-pressure foliations (Fig. 3) that were drawn from 616 foliation measurement sites (Stereoplot; Fig 3) filter variations of foliation direction occurring at scales lower than $100 \mathrm{~m}$. Therefore, they provide an excellent mapping tool to identify and characterize structures larger than this threshold. Two main types of structures are put in evidence: folds and fault zones (Figs. 3 and 4).

\subsection{1/ Map-scale folds}

On average, foliations dip westward with a mean N-NE trend. However, in three areas, Saint Florent, North of Cap Corse and southern rim of Castagniccia, a NE trend occurs with steep dips evolving from NW to SE. Three major synforms with a NE-SW trending axes affect the foliation, which from North to South are: the Centuri, the Saint Florent and the Aleria synforms (Figs. 3 and 4). In between, the deepest SL units (Castagniccia unit, Unit 4) 
form antiformal structures with $\mathrm{N}$ to $\mathrm{NE}$ axes, namely the Cap Corse and the Castagniccia antiforms (Fig. 3 and 4). The obliquity of synform and antiform axes reflects a superposition of different extensional events that we discuss below.

\subsection{2/ Map-scale fault zones}

Deflections and/or discontinuities of foliation trajectories define major fault zones at map-scale in both the ETSZ and the SL. These fault zones are not single faults but consist in narrow (from $100 \mathrm{~m}$ to $1 \mathrm{~km}$ wide) steeply-dipping corridors in which the foliation is downward bent, as it will be detailed below. They are associated to folds from some $\mathrm{km}$ to some $10 \mathrm{~km}$ scales. In these fault zones, meter-scale normal faults are widespread generally steeping at deeper angles than the foliation. As striaes are seldom observed on the fault planes it must be mentioned that the obliquity angle between faults and foliation indicates a dip-slip sense of shear or close to dip-slip. This validates the kinematic interpretation of these largescale fault zones.

We identify and map three main trends of these fault zones:

1/ N140 (grey in Figs. 3 and 4) mainly located at the rim of the Tenda massif (ETSZ) and locally within the SL nappes

2/ N60 $-70^{\circ}$ (red in Figs. 3 and 4 ) that control the foliation trend and define the three synforms of Centuri, St Florent and Aleria.

3/ N-S (blue in Fig.s 3 and 4) that mostly control the foliation trend in the eastern part of the island.

Cross-cutting relationships (Figs. 3 and 4) indicate that the three fault zone systems developed in the following order: N140 first, N60-70 ${ }^{\circ}$ second and N-S third.

\section{3/ Extension-related faulting and folding}




\section{1 / Alpine thrust reactivation: $N 140^{\circ}$ ductile faults}

The East Tenda Shear Zone, in the eastern rim of the Tenda massif (Fig. 3), is the most spectacular example of the extensional reactivation of an Alpine thrust that occurred during the ductile exhumation of the Tenda massif (Jolivet et al., 1998; Daniel et al.,1996; Gueydan et al., 2003; Molli et al., 2006). Figure 5 shows a NW-SE cross-section of the ETSZ (see location EE' in Fig. 3) that highlights the superposition of two main deformation stages, associated with two superposed ductile fabrics.

The first foliation S1 that bears HP mineral (crossite, phengite; Gueydan et al., 2003; Molli et al., 2006; Maggi et al., 2014) is associated to C'-type shear bands and antithetic rotation of stretched feldspars indicating a top-to-W sense of shear (Photo A; Fig 5) (see also discussion in Molli et al., 2006). Eastward, a progressive folding of the S1 foliation leads to the development of a new axial plane schistosity S2 (Fig. 5) with newly-formed greenschists minerals, attesting that S2 developped at lower pressure (Daniel et al., 1995; Gueydan et al., 2003; Molli et al, 2006). The ETSZ is characterized by a northeastward strain gradient (Photos C and D; Fig. 5) and is marked by: 1/ a progressive reduction of the grain size, 2/ a more penetrative S2 planar fabric and 3/ an increase of the number of C'-type shear bands with top-to-NE sense of shear (cross-section; Fig. 5). However, note that, close to the coastline, relicts of S1 folding can be found in the ETSZ mylonites. All together these observations attest for the extensional reactivation of the Alpine Thrust (SL/Tenda contact), as already documented by Molli et al. (2006). The strain gradient, from the core of the Tenda massif to the contact with the SL, was probably partly acquired during thrusting, since microlithons of folded S1 foliation in the mylonitic facies also show very small grain sizes (photo D; Fig 5,). 
The ETSZ is thus a demonstrative example of these N140 ductile normal fault zones (grey in Fig 3) that can be founded all along the SL/Tenda boundary but also along the SL/Hercynian basement boundary in Corsica (Molli, 2008). These N140 ${ }^{\circ}$ trending normal ductile fault zones are associated with retrograde metamorphic reactions and hence suggest that they contribute to the unroofing of the Tenda massif from $15-20 \mathrm{~km}$ to shallower levels while the SL were already in upper crustal conditions.

The two other observed fault zones trend $\left(\mathrm{N} 60-70^{\circ}\right.$ and $\left.\mathrm{N}-\mathrm{S}\right)$ are younger and not associated with metamorphic minerals and therefore affect both SL and Tenda in upper crustal - i.e. post-metamorphic- conditions.

\section{2/ Two stages of post-metamorphic faulting}

\subsection{1/ N60 $-70^{\circ}$ map-scale fault zones and foliation flexures}

In the Tenda massif, $\mathrm{N} 60^{\circ}-70^{\circ}$ trending map-scale fault zones affecting the ETSZ are identified thanks to a high resolution of foliation mapping and foliation trajectories (local map and stereoplot; Fig 6). Molli et al. (2006) already pointed out such strong variations in foliation trend, near St Florent and Santo Pietro di Tenda (see their Figs. 4, 7 and 10). The mean $\mathrm{N} 140^{\circ}$ trend of mylonitic foliation in the ETSZ changes abruptly and is re-oriented in a $\mathrm{N} 60^{\circ}-70^{\circ}$ direction within narrow deformation zones (Stereoplot and local map; Fig. 6). This evolution that occurred without any metamorphic mineral growth -i.e. post-metamorphic- is closely associated to normal faults trending $\mathrm{N} 65^{\circ}$ (stereoplot; Fig. 6). Note that this NE deformation zone is not a single normal fault but instead corresponds to a some hundred meters wide zone of distributed brittle-ductile deformation affecting pre-existing mylonitic fabrics (Fig. 6 a). This distributed character of deformation, instead of a more localized fault, 
is likely related to a strong mechanical anisotropy of the mylonites. This is illustrated by an attenuation of the deflexion of foliation trajectories away from the ETSZ, in relation with a decrease of the degree of pre-existing mylonitic anisotropy (Fig. 6a). In other words, the ETSZ is strongly reworked by $\mathrm{N} 60^{\circ}-70^{\circ}$ trending deformation zones giving arcuate patterns of foliation trajectories at map scales (up to 5-6 km; Figs. 3 and 6)

Similar arcuate foliation trajectories also occur in the SL of Alpine Corsica, within narrow $\mathrm{N} 60^{\circ}-70^{\circ}$ trending deformation zones, that correspond to flexures (see location of major flexures in Fig. 4). Flexures consist of localized folding, with steeply dipping axial planes and shallow plunging fold axes, always associated to asymmetric synforms and antiforms at regional scale. Two major flexures are observed onshore: one North of St Florent Syncline (Bastia flexure) and the other North of the Aleria Basin (Aleria flexure; Figs. 3 and 4).

Figure 7 shows a close-up North of Bastia, south of Erbalunga (see location in Fig 3) where, over a distance of around one kilometre, the foliations evolve from gently dipping to steeply dipping and gently dipping again, defining a couple of asymmetric antiform and synform in the fault zone footwall and hangingwall, respectively. Foliation measurements carried out at a favourable site (Stereoplot, Fig. 7) define an asymmetric fold with a horizontal axis oriented $\mathrm{N} 65^{\circ}$. Numerous normal faults with a mean $\mathrm{N}^{\circ} 5^{\circ}$ trend (Stereoplot; Fig. 6b) occur within the flexure with a top-to-SE sense of shear (Photographs; Figs. 7c and d).

On these bases, the flexure is the expression of a simple shear along a plane steeply dipping to the SE. In other words, instead of a single large normal fault, it is a deformation zone of distributed normal sense shearing accommodated by widespread small-scale normal faults. The above observations and measurements suggest that the foliation is first downward bent and, with the decrease of the angle between the shear direction and the foliation, the rock anisotropy become able to stimulate the development of a dominant set of normal faults at a 
low angle to the foliation (For a complete discussion of the mechanical effects of rock anisotropy see Cobbold et al 1971 and Cosgrove 1997).

In summary, the $\mathrm{N} 60^{\circ}-70^{\circ}$ oriented fault zone structures (Figs. 3 and 4) are either narrow zones of localized brittle-ductile deformation in mylonitic gneisses (Tenda units) or larger flexures (i.e. asymmetric folds) in the Schistes Lustrés s.l. Two major $\mathrm{N} 60^{\circ}-70^{\circ}$ trending zones affect the Alpine Corsica. The St Florent $\mathrm{N} 60^{\circ}-70^{\circ}$ trending fault zone is a broad zone of deformation, with $\mathrm{N} 60-70^{\circ}$ trending deformation zone in the Tenda massif and $\mathrm{N} 60^{\circ}-70^{\circ}$ trending flexure in the SL (Bastia Flexure; Fig. 3) that is associated to the St Florent basin depocenter. The Aleria $\mathrm{N} 60^{\circ}-70^{\circ}$ fault zone is a more localized zone of deformation, appearing at map-scale as a single normal fault that delimitates the lower Miocene sediments of the Aleria basin (Fig 3).

\subsection{2 / N-S structures}

Finally, N-S trending flexures are located to the Southeast of Castagniccia and along the eastern coastline of Cap Corse (Figs. 3 and 4). Figure 8 documents one of these N-S flexures, near the San Nicolao village (location on Fig. 3). Foliation trajectories rapidly change in few km from gently NE-dipping to steeply E-dipping with a N-S trend (outcrop pictures and map in Fig. 8). At map scale, this N-S trending fault zone controls the eastern limbs of both the Cap Corse anticline and the Castagniccia anticlines (Fig. 3), defining a mean N-S trend oblique to the NE-SW trends of the Centuri, St Florent and Aleria synclines (Figs. 3 and 4). The Cap-Corse and Castagniccia anticlines therefore reflect the superposition of two extensional deformation events, respectively associated to $\mathrm{N} 60^{\circ}-70^{\circ}$ and $\mathrm{N}-\mathrm{S}$ trending normal fault systems. In the Aleria basin, map-scale relationships (Fig. 3) illustrate i) that the N-S 
trending fault zone cross-cuts and offsets the $\mathrm{N} 60^{\circ}-70^{\circ}$ trending fault zone and ii) that a change in depocenter geometry associated to N-S faults occurred in middle Miocene.

\section{4/ Interpretation: Sequential extension}

The three types of extensional fault zones observed in Alpine Corsica can be dated using our compilation of geochronological ages (Fig. 2) and basin stratigraphy as reported in Figure 9 (see references in caption of Fig. 2).

\section{1/ Oligocene extensional reactivation of an Alpine thrust}

In the ETSZ, ${ }^{40} \mathrm{Ar} /{ }^{39} \mathrm{Ar}$ ages on minerals that define the $\mathrm{S} 1$ foliation yield an age ranging between 40 and 33 Ma while minerals that define the S2 foliation or C'-type shear bands with a top-to-E sense of shear yield ages between 32 and $25 \mathrm{Ma}$ (Brunet et al., 2002) (Fig. 9). Therefore, the extensional ductile reactivation of the $\mathrm{N} 140^{\circ}$ trending ductile Alpine Thrust (SL/Tenda massif contact) occurred during Oligocene. These N140 ${ }^{\circ}$ trending normal fault zones are associated with retrograde metamorphism suggesting that they contribute to the unroofing from a15-20 km depth of the Tenda massif to shallower crustal levels whereas the SL units were already in upper crustal conditions.

Whereas some onshore Oligocene deposits are known in Sardinia (see synthesis in Faccenna et al., 2002), there is no onshore Oligocene deposit in Corsica. Alpine Corsica was therefore most probably a structural high bounded by two major extensional faults (i.e. horst) trending $\mathrm{N} 140^{\circ}$ (offshore) during the Oligocene rifting. The Solenzara fault (N140 ${ }^{\circ}$ trending fault that bounds the Aleria Basin to the West, Fig. 3) acted as an extensional fault in Oligocene/early Miocene that controlled the deposition of Oligocene in the offshore part of the Bastia basin (see location in Fig. 1) (Mauffret et al.,1995; 1998). In summary, Oligocene 
rifting is accommodated in Alpine Corsica by the reactivation of an Alpine thrust resulting in the present day pattern of $\mathrm{N} 140^{\circ}$ trending fault zones, but without deposition and/or preservation of onshore sediments.

\section{2/ Burdigalian ramp-flat extension and onset of onshore basin deposition}

As quoted by Fellin et al. (2006) and Cavazza et al. (2007), the deposition of onshore Burdigalian basins is not related to the ductile exhumation of the Tenda massif. The novelty of our study is the tectonic framework that controlled basin deposition during this period, after Liguro-Provençal break-up and prior to Tyrrhenian rifting.

The $\mathrm{N} 60^{\circ}-70^{\circ}$ trending fault zones crosscut $\mathrm{N} 140^{\circ}$ trending fault zones and are therefore younger than Oligocene. The Aleria basin is controlled by such a $\mathrm{N} 60^{\circ}-70^{\circ}$ oriented fault zone, suggesting a Lower Miocene (Burdigalian) age of formation. In the Saint Florent basin, the bedding is NE-dipping, parallel to the foliation of the underlying basement (e.g. in SL in Fig. 3 and cross-section in Fig. 9b), with a mean $N 60^{\circ}-70^{\circ}$ trend. To the Southeast, the SL units show a similar trend however with a progressive increase of the dip angle (crosssection; Fig. 9).

The St Florent basin is lying conformably on top of the NW limb of the Castagniccia antiform (Figs. 3 and cross-section BB'; Fig. 9). The cross-section AA' presents the entire geometry of the Castagniccia antiform and the projected position of the Saint Florent basin (Fig. 9). The Tenda s.l. has been drawn below the SL as suggested by Molli (2008) using available geophysical studies (Berthout et al., 1999). The $\mathrm{N} 60^{\circ}-70^{\circ}$ oriented fault zones are reported in both Tenda and in the SL, as documented in the Figures 6 and 7, respectively. These fault zones define, in the SL nappe stack a narrow synform and a wide antiform, with a flat-lying antiform core. This fold geometry formed during the southeastward displacement of the SL nappe stack above a displacement surface with a ramp-flat geometry. The flat (i.e. 
décollement) corresponds to the interface between the SL and the Tenda basement and the ramp is a normal fault zone that cuts through the SL nappe stack (Castagniccia unit; Fig 9). Steep normal sense displacement along $\mathrm{N} 60^{\circ}-70^{\circ}$ trending ramp in the SL units (southeastern part of the cross-section AA', Fig. 9) likely corresponds to a normal fault affecting the Tenda basement underneath.

However, the AA' cross-section (Fig. 9) presents a geometry that suggests a least two stages of deformation during the ramp-flat extension. A two-stage model leading to the structure observed in cross-section AA', with two main units of SL (i.e. Castagniccia and the oceanic (lower and upper) units) and the Tenda, is proposed in Figure 10

1/ First, a classical ramp-flat extensional system inspired from analogue models (e.g. Roure et al 1992) with a ramp within the SL and flats between different SL units and between the SL and the Tenda (Lithological log in Fig. 10). The complex metamorphic nappe stack contains a number of weak layers, such as marbles layers on top of the Castagniccia units or serpentinite at the base of the Lower Oceanic units (see detailed lithological units in Fig. 3) that allowed easy layer-parallel shear (i.e. flat/décollement). Similarly, the contact between the SL (metamorphic units) and the Tenda s.l. (granitic basement) is a major weak zone. These two inherited weak layers acted as major décollements. Normal faulting of the Castagniccia units provided a ramp that connected the two décollements, allowing an extensional ramp-flat system to develop (Fig. 10a up). During extensional displacement, a syncline developed above the ramp in which the Saint Florent basin was deposited as a piggyback basin (Fig. 10a down). With increasing displacement the sedimentary layers deposited in the basin were tilted together with their basement (Castagniccia units) forming a rollover anticline. 
2/ Second, newly formed $\mathrm{N} 60^{\circ}-70^{\circ}$ trending fault zones crosscut the ramp-flat geometry (Figs. 10b and c) allowing the unroofing of the Tenda massif along its eastern border (see Fig. 5).

The resulting first-order geometry of the Alpine Corsica consists in two ramp-flat systems that controlled the deposition of the St Florent and Aleria basins, lately cross-cut by $\mathrm{N} 60^{\circ}-70^{\circ}$ steep normal fault zones (Fig. 10c). These two stages developed in sequence toward the SE. $\mathrm{N} 60^{\circ}-70^{\circ}$ trending fault zones and related ramp-flat extension occurred during Burdigalian, as exemplified by the syn-kinematic deposition of the Saint Florent piggyback basin. Therefore, the clustering of LT ages between 20 and 15 Ma can be interpreted as related to this major ramp-flat extensional system that lead to the unroofing/cooling of the SL and the Tenda (see compilation of ages in Fig. 11). Note however that new LT data along profiles perpendicular to the inferred $\mathrm{N} 60^{\circ}-70^{\circ}$ fault zones will be essential in a future study in order to better constrain the exact ages of activity of these structures (e.g. ages break across fault zones). In Sardinia, $\mathrm{N} 60^{\circ}-70^{\circ}$ trending faults controlled the deposition of lower Miocene basins (Faccenna et al., 2002 and references therein). To make the general process more easily understandable, we represent the ramp-flat extensional system with an initially flatlying geometry of the metamorphic nappe stack (Fig. 10). It is likely that the initial geometry of the nappe stack was more complex. To incorporate the complexities that our too simple model fails to explain, an assessment of the subsurface geometry through geophysical imaging (e.g. seismics) would be useful.

\section{3/ Serravalian $\mathrm{N}-\mathrm{S}$ extension at the onset of Tyrrhenian rifting}

$\mathrm{N}-\mathrm{S}$ trending fault zones are the youngest extensional structures in Corsica. They controlled a change in depocenter geometry in the Aleria basin during Langhian/Serravalian (Fig. 3). A Langhian/Serravalian unconformity is observed in the Bastia Basin (Fig. 1) that is 
the offshore extent of the Aleria Basin (Mauffret et al., 1999). This unconformity can result from the switch in fault zones trend from $\mathrm{N} 60^{\circ}$ to $\mathrm{N}-\mathrm{S}$ at the onset of Tyrrhenian rifting (Chamot-Rooke et al., 1999; Seranne; 1999; Faccenna et al., 2004). Low temperature ages younger than $15 \mathrm{Ma}$, mostly obtained in the eastern rim of Corsica are likely related to this event (Fellin et al., 2005; Fig. 11).

\section{4/ Corsica extension as a record of the Apennines slab deformation}

The above data and observations show that three stages of extension are recorded in Alpine Corsica (summarized in Fig. 11) : 1/ Oligocene with $\mathrm{N} 140^{\circ}$ oriented normal fault zones (extensional reactivation of an Alpine thrust), 2/ Burdigalian with ramp-flat extension and associated $\mathrm{N} 60^{\circ}-70^{\circ}$ trending normal fault zones/flexures and onshore deposition of piggy-back basins (St Florent and Aleria) and 3/ Langhian/Serravalian with N-S oriented fault zones responsible for a spatial change in the sedimentary depocenter in the onshore Aleria basin and an unconformity in the offshore Bastia basin. Our compilation of ages as well as basin stratigraphy allows an accurate dating of these three stages, with medium temperature (MT) cooling ages (Ar/Ar) for the first stage, low temperature (LT) ages and onshore basin deposition for Burdigalian (AFT and $\mathrm{U} / \mathrm{Th} / \mathrm{He}$ ) and LT (mainly $\mathrm{U}-\mathrm{Th} / \mathrm{He}$ ) together with the unconformity of the Langhian/Serravalian (Fig. 11).

Figure 12 presents the implications of these three stages of extension in the framework of Cenozoic kinematics of the central Mediterranean. Paleomagnetic data show that the Corso-Sardinian block underwent a ccw rotation along a vertical axis of $50^{\circ}-55^{\circ}$ between 21.5 Ma and 15 Ma (Gattacceca et al., 2007, and references in the introduction). Oligocene fault zones oriented $\mathrm{N} 140^{\circ}$ were initialy oriented $\mathrm{N} 15^{\circ}-20^{\circ}$-i.e. after restoration of the CorsoSardinian block in its Oligocene position- parallel to Oligocene normal faults in South East France (Seranne et al. 1999). The corresponding direction of stretching was NW-SE, 
consistent with the inferred southeastward Apennines slab rollback (Faccenna et al., 2004). At that time, the Alpine thrust was oriented almost perpendicular to the stretching direction and therefore ideally oriented for reactivation, and, as a consequence, unroofing of the Tenda massif. Basin deposition did not occur onshore but offshore on both sides of Corsica, in the Ligurian basin and in the Bastia basin (Mauffret, et al., 1995, 1998).

With the ccw rotation of Corsica, easy reactivation of the Alpine thrust progressively decreased. Therefore, new fault zones developed in Burdigalian trending $\mathrm{N} 60^{\circ}-70^{\circ}$, perpendicular to the NW-SE stretching direction. At regional scale, the en-échelon pattern of these $\mathrm{N} 60^{\circ}-70^{\circ}$ trending fault zones suggests a component of N-S dextral strike-slip motion along the Alpine thrust contact. Such a dextral strike-slip component along $\mathrm{N} 60^{\circ}-70^{\circ}$ trending normal fault zones in both Corsica (Maggi et al., 2014) and Sardinia (Faccenna et al. 2002) can be related to the progressive slab deformation during rollback toward the Southeast.

The development in Langhian/Serravalian of N-S trending fault zones indicates a major change in the direction of stretching and hence a switch of rollback direction from southeastward to eastward. This major change in slab rollback dynamics could likely be related to the onset of Africa collision, as recorded in Algeria/Tunisia, leading to a strong slab deformation between North Africa and Italy (Rosenbaum and Lister, 2004)

\section{7/ Conclusion}

Using an original compilation of geological and geochronological data together with newly acquired structural data, we evidence that three stages of extension were recorded in the exhumed metamorphic rocks of Alpine Corsica:

1) Oligocene extension accommodated by $\mathrm{N} 140^{\circ}$ trending fault zones corresponding to the extensional reactivation of an Alpine thrust; 
2) Burdigalian ramp-flat extension controlled by $\mathrm{N} 60^{\circ}-70^{\circ}$ trending fault zones that allowed onshore piggy-back basin developpement (e.g. St Florent basin)

3) Serravalian N-S trending fault zones associated to a major unconformity in the offshore Bastia basin..

These three stages of extensional deformation were related to the progressive Apennines slab rollback. Alpine Corsica was the overriding plate of the Apennines slab during the $30 \mathrm{My}$ of rollback and has therefore recorded a large part of the slab rollback history, from southwestward, responsible for Oligocene rifting and opening of the LiguroProvençal basin to eastward due the onset of slab tearing in Sicily in Serravalian.

\section{Aknowledgements}

This project was launched and performed during spring field trips of Master degree students of Rennes 1 university from 2007 to 2010 and then of Montpellier 2 university from 2011 to 2013. Funding from UFR SPM of Université Rennes 1 and Faculté des Sciences, Université Montpellier 2, are thanked for travelling and accommodation. Nathan Cogné, Bernard Celerier and Gianluca Frasca are thanked for their help in data acquisition. Many thanks to Anne Delplanque for figure drawing. Constructives reviews by Giancarlo Molli and one anonymous reviewer as well as the professional handling of Tatsuya Ishiyama (Guest Editor) and Rob Govers (Editor-in-Chief) helped improving the manuscript.

\section{REFERENCES}


Austrheim, H., \& Andersen, T. B. (2004). Pseudotachylytes from Corsica: fossil earthquakes from a subduction complex. Terra nova 16, 193-197.

Amaudric du Chaffaut, S., Bonin, B., Caron, J.M., Conchon, O. and Rossi, P. (1985)- Carte géol. France (1/50000), feuille Venaco (1114) — Orléans : BRGM. Notice explicative par Amaudric du Chaffaut et al. (1985), 45p.

Andersen, T. B. and H. Austrheim (2006). Fossil earthquakes recorded by pseudotachylytes in mantle peridotite from the Alpine subduction complex of Corsica. Earth and Planetary Science Letters 242(1-2): 58-72.

Bache, F., Olivet, J. L., Gorini, C., Aslanian, D., Labails, C., Rabineau, M., 2010. Evolution of rifted continental margins: The case of the Gulf of Lions (Western Mediterranean Basin). Earth and Planetary Science Letters, 292, 345-356.

Bethoux, N., A. Deschamps, G. Nolet, E. Bertrand, I. Contrucci, M. Sosson and J. Ferrandini (1999). The deep structure of Corsica as inferred by a broad band seismological profile. Geophysical Research Letters 26(17): 2661-2664.

Brunet, C., P. Monié, L. Jolivet and J. P. Cadet (2000). Migration of compression and extension in the Tyrrhenian Sea, insights from 40Ar/39Ar ages on micas along a transect from Corsica to Tuscany. Tectonophysics 321(1): 127-155.

Caron, J.M. 1994. Metamorphism and deformation in Alpine Corsica. Schweizerische Mineralogische und Petrographische Mitteilungen, 7, 105-114. 
Caron, J.M., Loye-Pilot, M.-D., Conchon, O., and Scius, H., 1990, Carte géologique de la France (1/50,000), feuille Pietra di Verde (1115). Orléans: BRGM. Notice explicative par Caron et al. (1990), 51p.

Cavazza, W., DeCelles, P. G., Fellin, M. G., Paganelli, L., 2007. The Miocene Saint-Florent Basin in northern Corsica: stratigraphy, sedimentology, and tectonic implications. Basin Research 19, 507-527.

Chamot-Rooke, N., Gaulier, J. M., Jestin, F., 1999. Constraints on Moho depth and crustal thickness in the Liguro-Provençal basin from a 3D gravity inversion: geodynamic implications. Geological Society, London, Special Publications 156, 37-61.

Cobbold, P. R., J. W. Cosgrove and J. M. Summers (1971). Development of internal structures in deformed anisotropic rocks. Tectonophysics 12(1): 23-53.

Cohen, C.R., Schweickert, R.A., and Odom, A.L., 1981, Age of emplacement of the schistes lustres nappe, Alpine Corsica: Tectonophysics, v. 73, p. 267-283.

Cosgrove, J. W. (1997). The influence of mechanical anisotropy on the behaviour of the lower crust. Tectonophysics 280(1-2): 1-14.

Daniel, J. M., Jolivet, L., Goffe, B., Poinssot, C., 1996. Crustal-scale strain partitioning: footwall deformation below the Alpine Oligo-Miocene detachment of Corsica. Journal of Structural Geology 18, 41-59. 
Danisík, M., Kuhlemann, J., Dunkl, I., Székely, B., and Frisch, W., 2007, Burial and exhumation of Corsica (France) in the light of fission track data: Tectonics, v. 26, p. TC1001.

Edel, J.B., Montigny, R., and Thuizat, R., 1981, Late Paleozoic rotations of Corsica and Sardinia: New evidence from paleomagnetic and K-Ar studies: Tectonophysics, v. 79, p. 201-223.

Edel, J. B., Dubois, D., Marchant, R., Hernandez, J., Cosca, M., 2001. La rotation miocene inferieur du bloc corso-sarde; nouvelles contraintes paleomagnetiques sur la fin du mouvement. Bulletin de la Société géologique de France 172, 275-283.

Faccenna, C., F. Speranza, F. D. A. Caracciolo, M. Mattei and G. Oggiano (2002).

Extensional tectonics on Sardinia (Italy): insights into the arc-back-arc transitional regime. Tectonophysics 356(4): 213-232.

Faccenna, C., Piromallo, C., Crespo-Blanc, A., Jolivet, L., Rossetti, F., 2004. Lateral slab deformation and the origin of the western Mediterranean arcs. Tectonics 23, TC1012.

Fellin, M.G., Zattin, M., Picotti, V., Reiners, P.W., Nicolescu, S., 2005, Relief evolution in northern Corsica (western Mediterranean): Constraints on uplift and erosion on longterm and short-term timescales: Journal of Geophysical Research, 110, F01016, doi:10.1029/2004JF000167. 
Fellin, M. G., Vance, J. A., Garver, J. I., Zattin, M., 2006. The thermal evolution of Corsica as recorded by zircon fission-tracks. Tectonophysics, 421, 299-317.

Ferrandini, J., Rossi, P., Ferrandini, M., Farjanel, G., Ginsburg, L., Schuler, M., Geissert, F., 1999. La formation conglomératique du Vazzio près d'Ajaccio (Corse-du-Sud), un témoin des dépôts du Chattien supérieur continental synrift en Méditerranée occidentale. Comptes Rendus de l'Académie des Sciences-Series IIA-Earth and Planetary Science 329, 271-278.

Ferrandini, J., Gattacceca, J., Ferrandini, M., Deino, A., and Janin, M.C., 2003, Chronostratigraphie et paléomagnétisme des dépôts oligo-miocènes de Corse : implications géodynamiques pour l'ouverture du bassin liguro-provençal Bulletin de la Société Géologique de France, v. 174, p. 357-371.

Fournier, M., L. Jolivet, B. Goffé and R. Dubois (1991). Alpine Corsica Metamorphic Core Complex. Tectonics 10(6): 1173-1186.

Gattacceca, J., Deino, A., Rizzo, R., Jones, D. S., Henry, B., Beaudoin, B., Vadeboin, F., 2007. Miocene rotation of Sardinia: new paleomagnetic and geochronological constraints and geodynamic implications. Earth and Planetary Science Letters 258, 359-377.

Gueguen, E., Doglioni, C., Fernandez, M., 1998. On the post-25 Ma geodynamic evolution of the western Mediterranean. Tectonophysics 298, 259-269. 
Gueydan, F., Leroy, Y. M., Jolivet, L., Agard, P., 2003. Analysis of continental midcrustal strain localization induced by microfracturing and reaction-softening. Journal of Geophysical Research: Solid Earth 108, B2.

Guieu, G., Loye-Pilot, M.D., Mathely, J., Bercovici, C., Gaviglio, P. (1994) - Carte géol. France (1/50000), feuille Cervione (1111). Orléans: BRGM. Notice explicative par G. Guieu et al. (1994), 50 p.

Handy, M.R., Schmid, S.M., Bousquet, R., Kissling, E., Bernoulli, D. (2010): Reconciling plate-tectonic reconstructions with the geological-geophysical record of spreading and subduction in the Alps. Earth Science Reviews, 102, 121-158.

Harris, L. (1985). "Progressive and polyphase deformation of the Schistes Lustrés in Cap Corse, Alpine Corsica." Journal of Structural Geology 7(6): 637-650.

Jauzein, A., Orszag-Sperber, F., Pilot, M.D. (1985)-Carte géol. France (1/50000), feuille Ghisonaccia (1119) - Orléans : BRGM. Notice explicative par Jauzein et al. (1985), $28 \mathrm{p}$.

Jolivet, L., C. Faccenna, B. Goffe, M. Mattei, F. Rossetti, C. Brunet, F. Storti, R. Funicielli, J. P. Cadet, N. d'Agostino and T. Parra (1998). "Midcrustal shear zones in postorogenic extension: Example from the northern Tyrrhenian Sea." Journal of Geophysical Research 103(B6): 12,123-112,160. 
Jolivet, L., Daniel, J. M., Fournier, M., 1991. Geometry and kinematics of extension in Alpine Corsica. Earth and Planetary Science Letters 104, 278-291.

Jolivet, L., Dubois, R., Fournier, M., Goffé, B., Michard, A., Jourdan, C., 1990. Ductile extension in alpine Corsica. Geology, 18, 1007-1010.

Lahondère, D., 1996. Les schistes bleus et les éclogites à lawsonite des unités continentales et océaniques de la Corse alpine: nouvelles données pétrologiques et structurale. $\mathrm{PhD}$ thesis.

Lahondère, D., and Guerrot, C., 1997, Datation Sm/Nd du métamorphisme éclogitique en Corse Alpine: un argument pour l'existence au Crétacé Supérieur d'une zone de subduction active localisée sous le bloc corso-sarde: Géologie de la France, v. 3, p. 311.

Lahondère J.C., Durand-Delga, M., Lluch, D., Guillou, J.J., Primel L., Ohnenstetter, M.

- (1992) - Carte géol. France (1/50000), feuille Luri (1102) - Orléans :BRGM. Notice explicative par J.C. Lahondère et al. (1992), 50 p.

Lahondère J.C. (1983). - Carte géol. France (1/50000), feuille Bastia (1104). Orléans : BRGM. Notice explicative par Lahondère J.C. (1983),41p.

Lahondère J.C., Conchon, O., Lahondère D. (1994). — Carte géol. France (1/50 000), feuille Vescovato (1107). Orléans : BRGM. Notice explicative par J.C. Lahondère et al. (1994), $67 \mathrm{p}$. 
Maggi, M., Rossetti, F., Ranalli, G., Theye, T., 2014. Feedback between fluid infiltration and rheology along a regional ductile-to-brittle shear zone: The East Tenda Shear Zone (Alpine Corsica). Tectonics 33, 253-280.

Malasoma, A., Marroni, M., Musumeci, G., Pandolfi, L., 2006. High-pressure mineral assemblage in granitic rocks from continental units, Alpine Corsica, France. Geological Journal 41, 49-59.

Malasoma, A., Marroni, M., 2007. HP/LT metamorphism in the Volparone Breccia (Northern Corsica, France): evidence for involvement of the Europe/Corsica continental margin in the Alpine subdution zone. Journal of Metamorphic Geology 25, 529-545.

Malavieille, J., Chemenda, A., Larroque, C., 1998. Evolutionary model for Alpine Corsica: mechanism for ophiolite emplacement and exhumation of high-pressure rocks. Terra Nova 10, 317-322.

Malusà, M. G., C. Faccenna, S. L. Baldwin, P. G. Fitzgerald, F. Rossetti, M. L. Balestrieri, M. Danišík, A. Ellero, G. Ottria, and C. Piromallo (2015), Contrasting styles of (U)HP rock exhumation along the Cenozoic Adria-Europe plate boundary (Western Alps, Calabria, Corsica), Geochem. Geophys. Geosyst., 16, 1786-1824, doi:10.1002/2015GC005767.

Maluski, H., Mattauer, M., Matte, P. 1973. Sur la présence de decrochement alpins en Corse. Compte Rendu Académie Science Paris, serie D, 276, 709-712. 
Mattauer, M., M. Faure and J. Malavieille (1981). "Tectonics Transverse lineation and largescale structures related to Alpine obduction in Corsica." Journal of Structural Geology 3(4): 401-409.

Michard, A., Chalouan, A., Feinberg, H., Goffé, B., Montigny, R., 2002. How does the Alpine belt end between Spain and Morocco?. Bulletin de la Société géologique de France 173, 3-15.

Mauffret, A., Pascal, G., Maillard, A., Gorini, C., 1995. Tectonics and deep structure of the north-western Mediterranean Basin. Marine and petroleum geology 12, 645-666.

Mauffret, A., Contrucci, I., Brunet, C., 1999. Structural evolution of the Northern Tyrrhenian Sea from new seismic data. Marine and Petroleum Geology 16, 381-407.

Molli, G., Tribuzio, R., Marquer, D., 2006. Deformation and metamorphism at the eastern border of the Tenda Massif (NE Corsica): a record of subduction and exhumation of continental crust. Journal of Structural Geology 28, 1748-1766.

Molli, G., 2008. Northern Apennine-Corsica orogenic system: an updated overview. Geological Society, London, Special Publications 298, 413-442.

Montigny, R., Edel, J.B., and Thuizat, R., 1981, Oligo-Miocene rotation of Sardinia: K/Ar ages and paleomagnetic data of Tertiary volcanics: Earth and Planetary Science Letters, v. 54, p. 295-349. 
Ravna, E.J.K., Andersen, B., Jolivet, L., De Capitani, C., 2010. Cold subduction and the formation of lawsonite eclogite - constraints from prograde evolution of eclogitized pillow lava from Corsica. Journal of Metamorphic Geology 28, 381-395.

Rehault, J. P., 1981. Evolution tectonique et sédimentaire du bassin Ligure (Méditerranée occidentale). $\mathrm{PhD}$ thesis.

Rosenbaum, G., Lister, G. S., Duboz, C., 2004. The Mesozoic and Cenozoic motion of Adria (central Mediterranean): a review of constraints and limitations. Geodinamica Acta 17, 125-139.

Rosenbaum, G., Lister, G. S., 2004. Neogene and Quaternary rollback evolution of the Tyrrhenian Sea, the Apennines, and the Sicilian Maghrebides. Tectonics 23, TC1013.

Rossi, P., Durand-Delga, M., Lahondère, J.C. et al. (2001) - Carte géol. France (1/50 000), feuille Santo-Pietro-di-Tenda (1106). Orléans : BRGM. Notice explicative par Rossi et al. (2001), $224 \mathrm{p}$.

Rossi, P., Lahondère, J.C., Lluch, D., Loye-Pilot, M.D., Jacquet (1994a). - Carte géol. France (1/50000), feuille Saint-FIorent (1103). Orléans : BRGM. Notice explicative par Rossi et al. (1994),93p.

Rossi, P, et al. (1994b). - Carte géol. France (1/50000), feuille Corte (1110). Orléans : BRGM. Notice explicative par P. Rossi et al. (1994), 150 p. 
Rossi, P., Lahondère, J.-C., Loyë, M.D., Conchon, O., Gauthier, A. (2012) - Carte géol. France (1/50 000), feuille Bastelica (1118). Orléans : BRGM. Notice explicative Rossi et al., (2012), $134 \mathrm{p}$.

Roure F., Brun J-P., Colletta B., and Van Den Driessche (1992). Geometry and kinematics of extensional structures in the Alpine Foreland Basin of Southeastern France. Journal of Structural Geology, Oxford, 14 (5) : 503-519.

Séranne, M., 1999. The Gulf of Lion continental margin (NW Mediterranean) revisited by IBS: an overview. Geological Society, London, Special Publications 156, 15-36.

Vitale Brovarone, A. and D. Herwartz (2013). "Timing of HP metamorphism in the Schistes Lustrés of Alpine Corsica: New Lu-Hf garnet and lawsonite ages." Lithos 172-173: 175-191.

Vitale Brovarone, A., Beltrando, M., Malavieille, J., Giuntoli, F, Tondella, E, Groppo, C., Beyssac, O., Compagnoni, R., 2011. Inherited Ocean-Continent Transition zones in deeply subducted terranes: Insights from Alpine Corsica. Lithos 124, 273-290, doi: 10.1016/j.lithos.2011.02.013.

Vitale Brovarone, A., Beyssac, O., Malavieille, J., Molli G., Beltrando, M. Compagnoni, R., 2013. Stacking and metamorphism of continuous segments of subducted lithosphere in a high-pressure wedge: the example of Alpine Corsica (France). Earth Science Reviews 116, 35-56. 
Wortel, M. J. R., Spakman, W., 2000. Subduction and slab detachment in the MediterraneanCarpathian region. Science 290, 1910-1917.

Zarki-Jakni, B., van der Beek, P., Poupeau, G., Sosson, M., Labrin, E., Rossi, P., and Ferrandini, J., 2004, Cenozoic denudation of Corsica in response to Ligurian and Tyrrhenian extension: Results from apatite fission track thermochronology: Tectonics, v. 23, p. TC1003.

\section{Figures Caption}

Figure 1/ Tectonic map of the Central Mediterranean, showing the onshore and offshore basins with ages of rifting and seafloor spreading if exist.

Figure 2/ Compilation of geochronological ages and of onshore Corsica basins (Saint Florent, Francardo and Aleria, located in Fig. 3) and Liguro-Provençal and Tyrrhenian sea rifting. Data are from Brunet et al., 2000; Cohen et al., 1981; Maluski, 1977; Lahondère and Guerrot, 1997 for Ar/Ar and Nd/Sm ages from Danisík et al., 2007; Fellin et al., 2005, 2006; ZarkiJakni et al., 2004 for fission track data (AFT, ZFT and U-Th/He), from Bache et al., 2010; Chamot-Rooke et al., 1999; Edel et al., 2001; Edel et al., 1981; Ferrandini et al., 2003; Ferrandini et al., 1999; Montigny et al., 1981 for Tyrrhenian and Liguro Provençal basins.

Figure 3/ Tectonic map of Alpine Corsica with HP foliation trajectories (from our data shown in Stereoplot), major ductile and brittle deformation zones (N140 in grey; $\mathrm{N} 60^{\circ}-70^{\circ}$ in red; 
$\mathrm{N}-\mathrm{S}$ in blue). Detailed lithologies and names of Alpine nappe units (with numbers referring to units numbering in the main text) shown as a tectonic log.

Figure 4/ Major tectonic structures of Alpine Corsica, extracted from Figure 3. Faults/deformation zones: $\mathrm{N} 140^{\circ}$ in grey, $\mathrm{N} 60^{\circ}-70^{\circ}$ in red and $\mathrm{N}-\mathrm{S}$ in blue. Large-scale folds (from North to South): Centuri Synform, Cap Corse antiform, St Florent Synform, Castagniccia antiform, Aleria Synform. Major $\mathrm{N} 60^{\circ}-70^{\circ}$ trending fault zones/flexures discussed in this paper: Bastia and Aleria.

Figure 5/ N140 ductile fault zones: SW-NE cross-section in the East Tenda Shear Zone (ETSZ, location EE' in Figs. 4 and 6 ) showing the superposition of two deformation events (D1 and D2). A-B-C/ Outcrop photographs of the main types of structures. See locations on the cross-section.

Figure 6/ N60 $-70^{\circ}$ fault zones in the Tenda massif (location in Fig. 4): A/ Detailed tectonic map of the ETSZ with $160^{\circ}-70^{\circ}$ trending normal fault zones and locations of cross-sections EE' (shown in Fig. 5) and FF' (shown in D/). B-C/ Stereoplots of foliations and faults measurements. D/ NNW-SSE cross-section (location FF' in A/) showing the rework of the ETSZ (N140 fault zone) by N60-70 fault zones. E/ Outcrop photographs (location in D/).

Figure 7. Structures and $\mathrm{N} 60^{\circ}-70^{\circ}$ fault zones associated to the Bastia flexure in the Schistes Lustrés. A/ Stereoplot of foliations measurements. B/ Detailed structural map of the $\mathrm{N} 60^{\circ}-70^{\circ}$ Bastia flexure (See location in Fig. 4) with km-scale asymmetrical anticline (stereoplot of

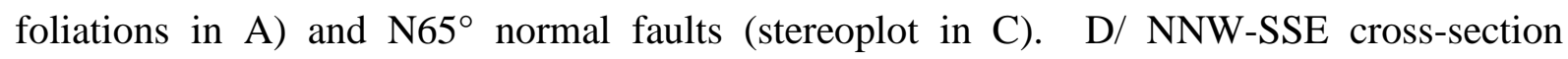


(location $\mathrm{FF}^{\prime}$ in $\mathrm{B} /$ ) showing the deformation zone (flexure in light red) associated with N6070 fault zones (see text for further details). E and F/ Outcrop photographs (location in D/).

Figure 8/ N-S fault zones in the Schistes Lustrés in the vicinity of San Nicolao (See location in Fig. 3). A/ Detailed structural map illustrating the change in foliation trends. B/ E-W crosssection (location $\mathrm{HH}^{\prime}$ in $\mathrm{A} /$ ) showing the deformation zone (flexure in light blue) associated with N-S fault zones (see text for further details). C/ outcrop photographs of steeply dipping foliations (location in $\mathrm{B} /$ )..

Figure 9/ Simplified geological cross-section of the St Florent basin and its basement (Section BB') and of the Castagniccia anticline (Section AA'). See location of the two sections in Figure 3

Figure 10/ Simple geometrical two-stage model of a ramp-flat extensional system with location of piggy-back basins. A/ "Realistic" pre-extensional sytem (Alpine nappes pile, redraw from Molli 2008) with location as a rectangle of simplified models shown in B/, C/ and $\mathrm{D} /, \mathrm{B}$ / one ramp model with initial (up) and deformed (down) geometry; C/ one ramp model and late normal faulting; D/ two ramp model and late normal faulting; Compare with the complex geometry of cross-section AA' in Fig. 9

Figure 11/ Ages of the three extensional stages and related regional-scale structures/ fault zones (N140 ${ }^{\circ}$ in grey; N60-70 in red; N-S in blue) based on our compilation of ages (see Fig. 2). 
Figure $12 /$ Geodynamic significance of $\mathrm{N} 140^{\circ}$ ductile fault zones (left), N60 $-70^{\circ}$ ramp-flat extension (middle) and N-S fault zones (right) in the tectonic framework of the central Mediterranean and of the Apennines slab rollback (modified from Faccenna et al., 2004). 


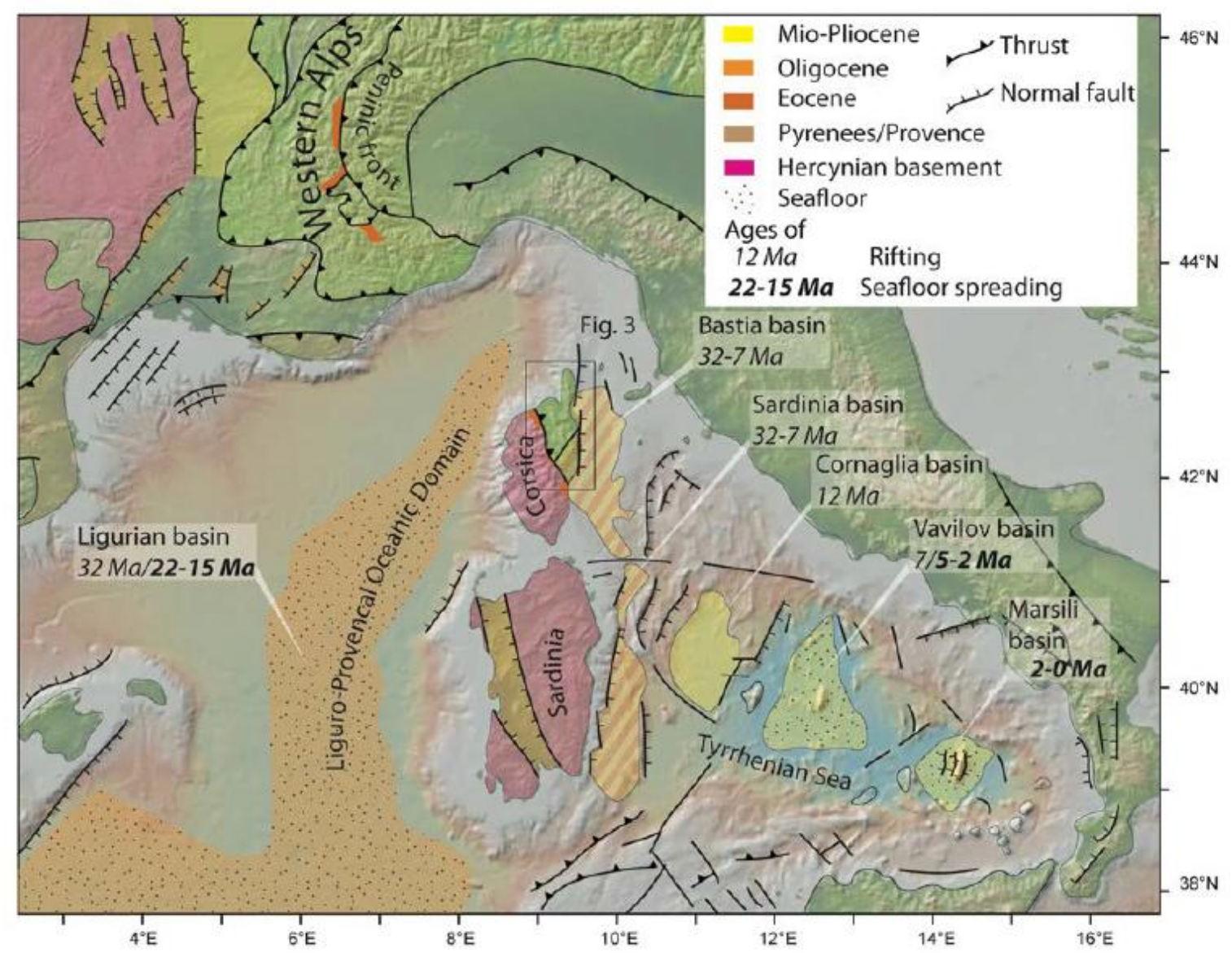

Figure 1/ Tectonic map of the Central Mediterranean, showing the onshore and offshore basins with ages of rifting and seafloor spreading if exist. 


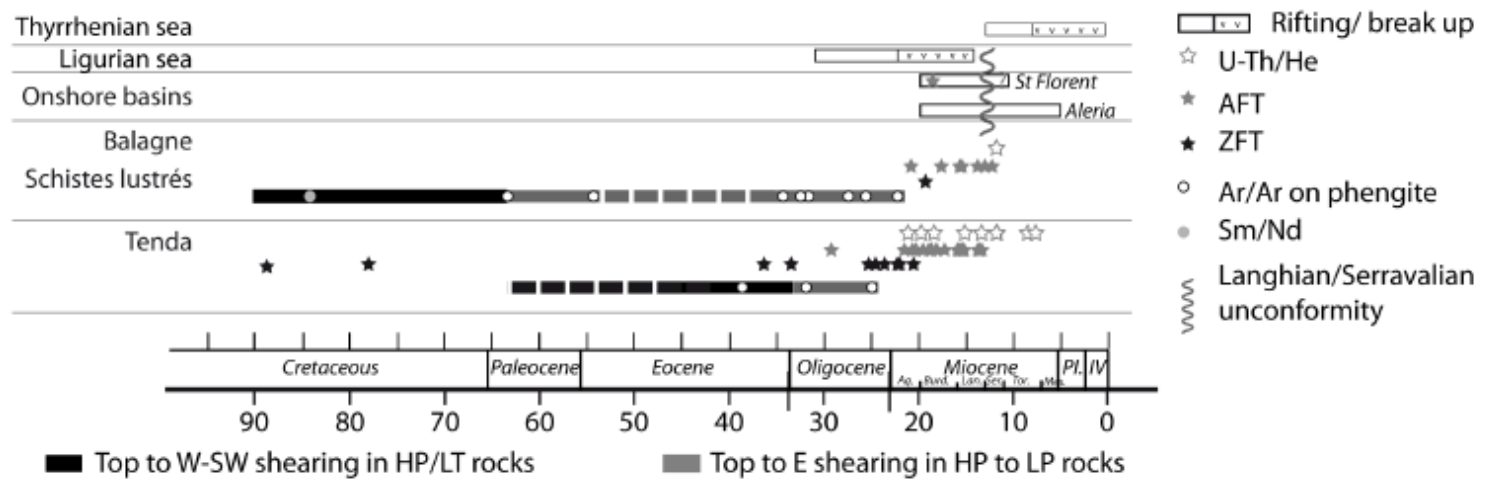

Figure 2/ Compilation of geochronological ages and of onshore Corsica basins (Saint Florent, Francardo and Aleria, located in Fig. 3) and Liguro-Provençal and Tyrrhenian sea rifting. Data are from Brunet et al., 2000; Cohen et al., 1981; Maluski, 1977; Lahondère and Guerrot, 1997 for $\mathrm{Ar} / \mathrm{Ar}$ and Nd/Sm ages from Danisík et al., 2007; Fellin et al., 2005, 2006; Zarki-Jakni et al., 2004 for fission track data (AFT, ZFT and U-Th/He), from Bache et al., 2010; Chamot-Rooke et al., 1999; Edel et al., 2001; Edel et al., 1981; Ferrandini et al., 2003; Ferrandini et al., 1999; Montigny et al., 1981 for Tyrrhenian and Liguro Provençal basins. 


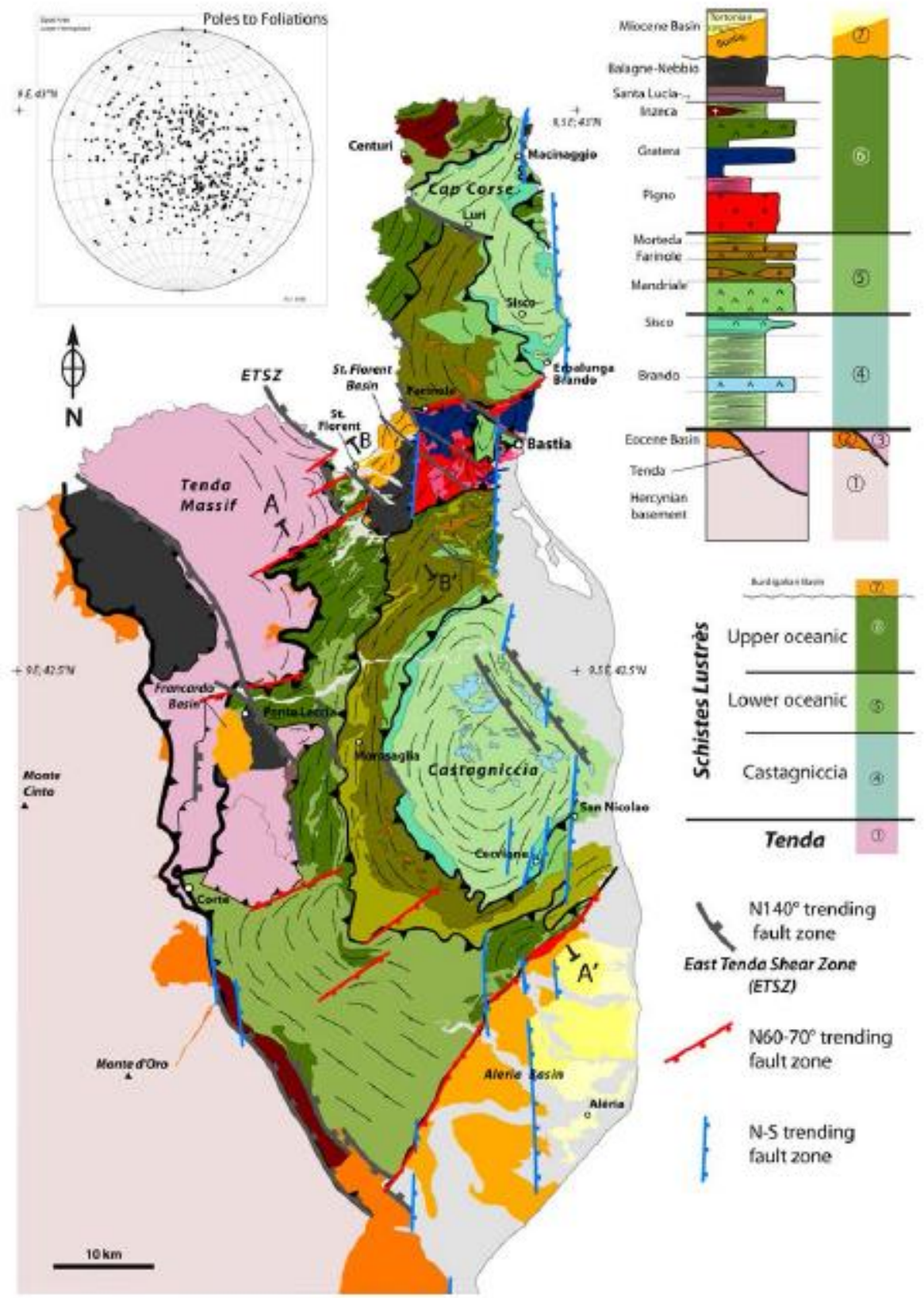

Figure 3/ Tectonic map of Alpine Corsica with HP foliation trajectories (from our data shown in Stereoplot), major ductile and brittle deformation zones (N140 ${ }^{\circ}$ in grey; $\mathrm{N} 60^{\circ}-70^{\circ}$ in red; $\mathrm{N}-\mathrm{S}$ in blue). Detailed lithologies and names of Alpine nappe units (with numbers referring to units numbering in the main text) shown as a tectonic log. 


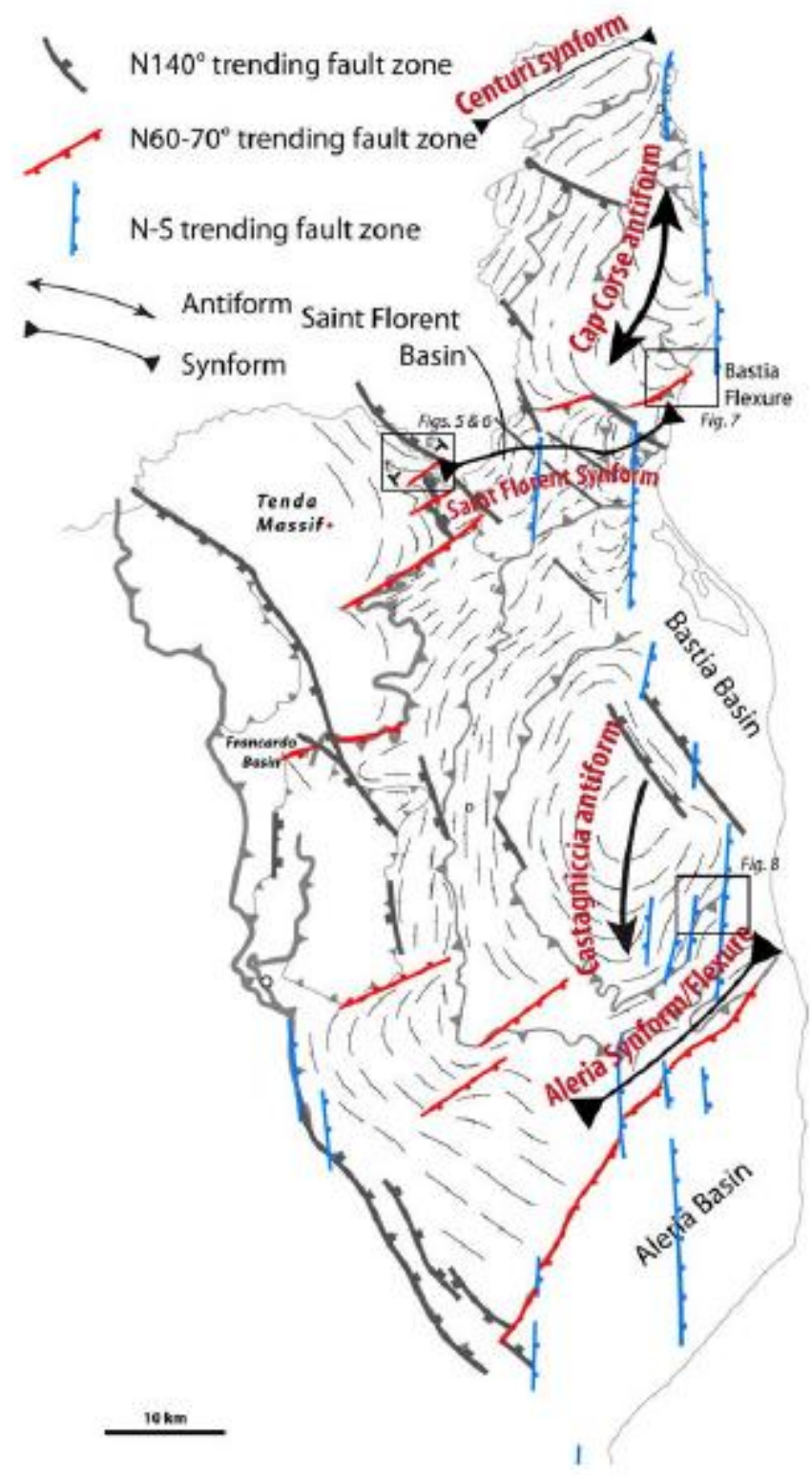

Figure 4/ Major tectonic structures of Alpine Corsica, extracted from Figure 3. Faults/deformation zones: $\mathrm{N} 140^{\circ}$ in grey, $\mathrm{N} 60^{\circ}-70^{\circ}$ in red and N-S in blue. Largescale folds (from North to South): Centuri Synform, Cap Corse antiform, St Florent Synform, Castagniccia antiform, Aleria Synform. Major $\mathrm{N} 60^{\circ}-70^{\circ}$ trending fault zones/flexures discussed in this paper: Bastia and Aleria. 

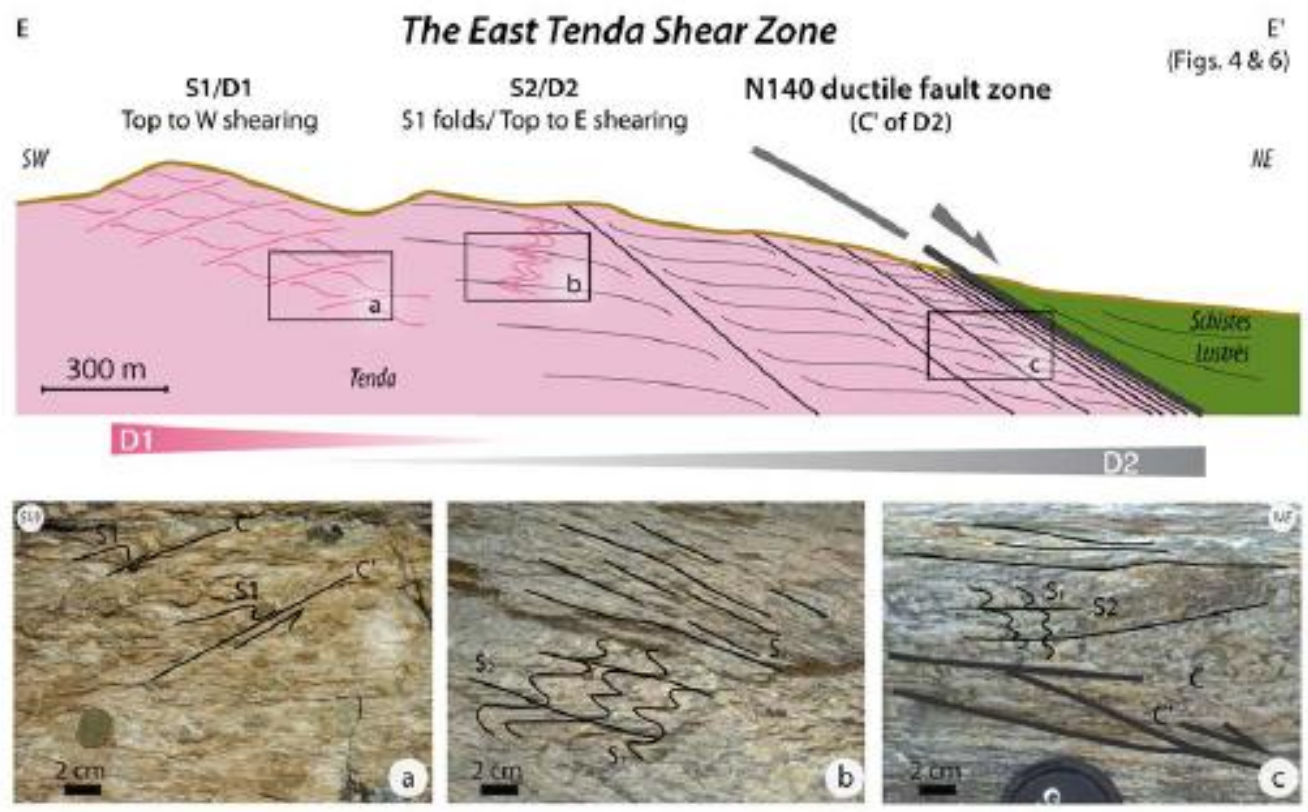

Figure 5/ N140 ductile fault zones: SW-NE cross-section in the East Tenda Shear Zone (ETSZ, location EE' in Figs. 4 and 6 ) showing the superposition of two deformation events (D1 and D2). A-B-C/ Outcrop photographs of the main types of structures. See locations on the cross-section. 

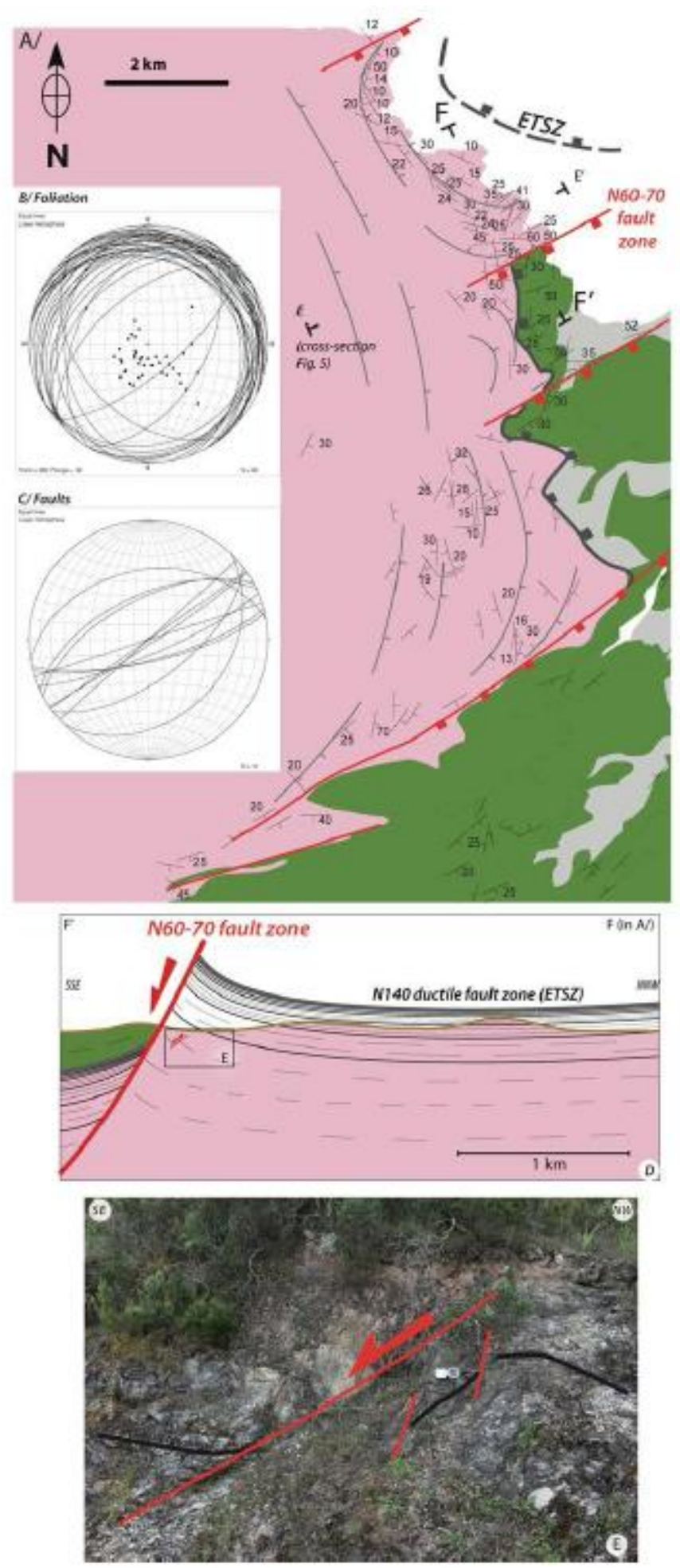

Figure 6/ $\mathrm{N} 60^{\circ}-70^{\circ}$ fault zones in the Tenda massif (location in Fig. 4): A/ Detailed tectonic map of the ETSZ with $\mathrm{N} 60^{\circ}-70^{\circ}$ trending normal fault zones and locations of cross-sections EE' (shown in Fig. 5) and FF' (shown in D/). B-C/ Stereoplots of foliations and faults measurements. D/ NNW-SSE cross-section (location FF' in A/) showing the rework of the ETSZ (N140 fault zone) by N60-70 fault zones. E/ Outcrop photographs (location in D/). 

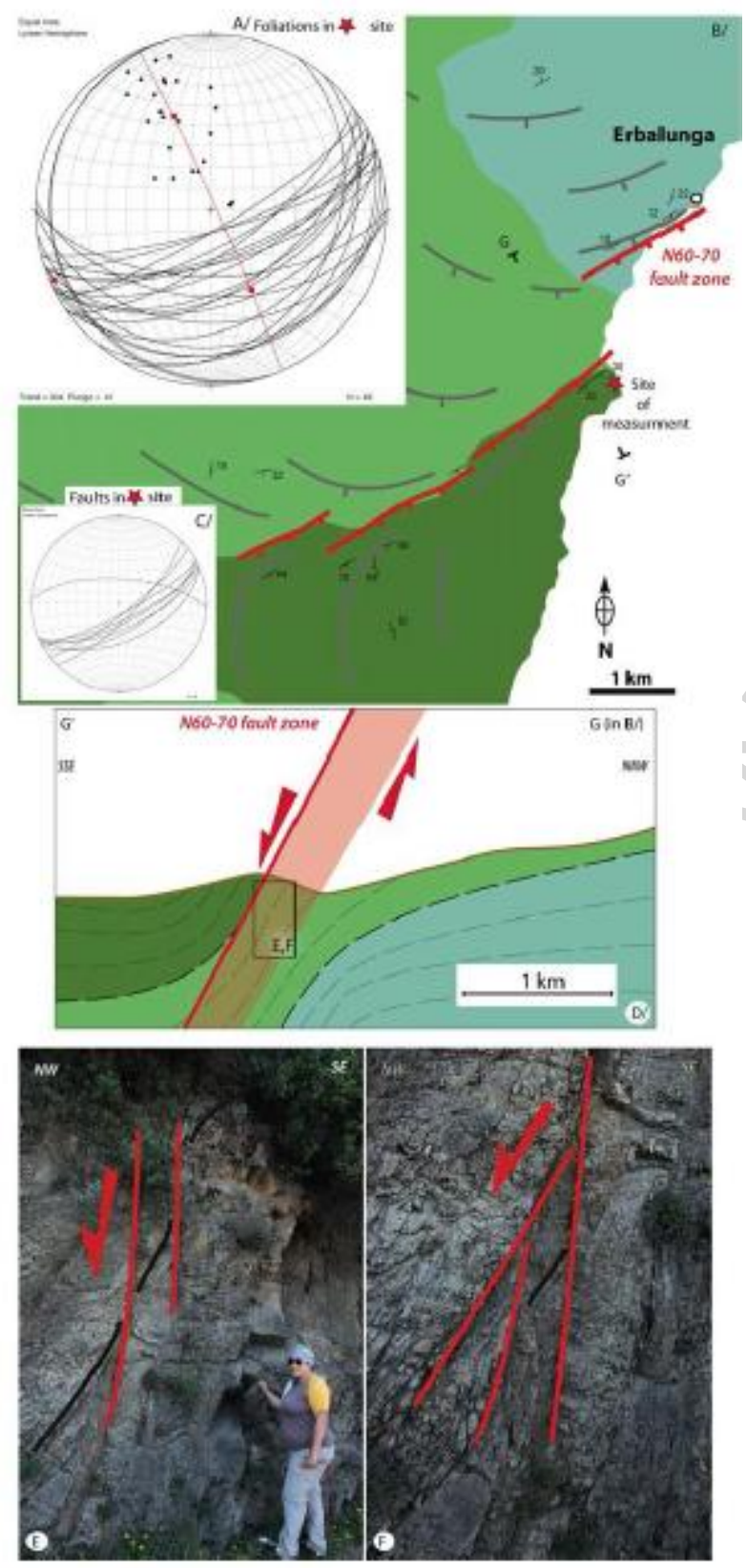

Figure 7. Structures and $\mathrm{N} 60^{\circ}-70^{\circ}$ fault zones associated to the Bastia flexure in the Schistes Lustrés. A/ Stereoplot of foliations measurements. B/ Detailed structural map of the $\mathrm{N} 60^{\circ}-70^{\circ}$ Bastia flexure (See location in Fig. 4) with km-scale asymmetrical anticline (stereoplot of foliations in $\mathrm{A}$ ) and $\mathrm{N} 65^{\circ}$ normal faults (stereoplot in C). D/ NNW-SSE cross-section (location FF' in B/) showing the deformation zone (flexure in light red) associated with N60-70 fault zones (see text for further details). E and F/ Outcrop photographs (location in D/). 

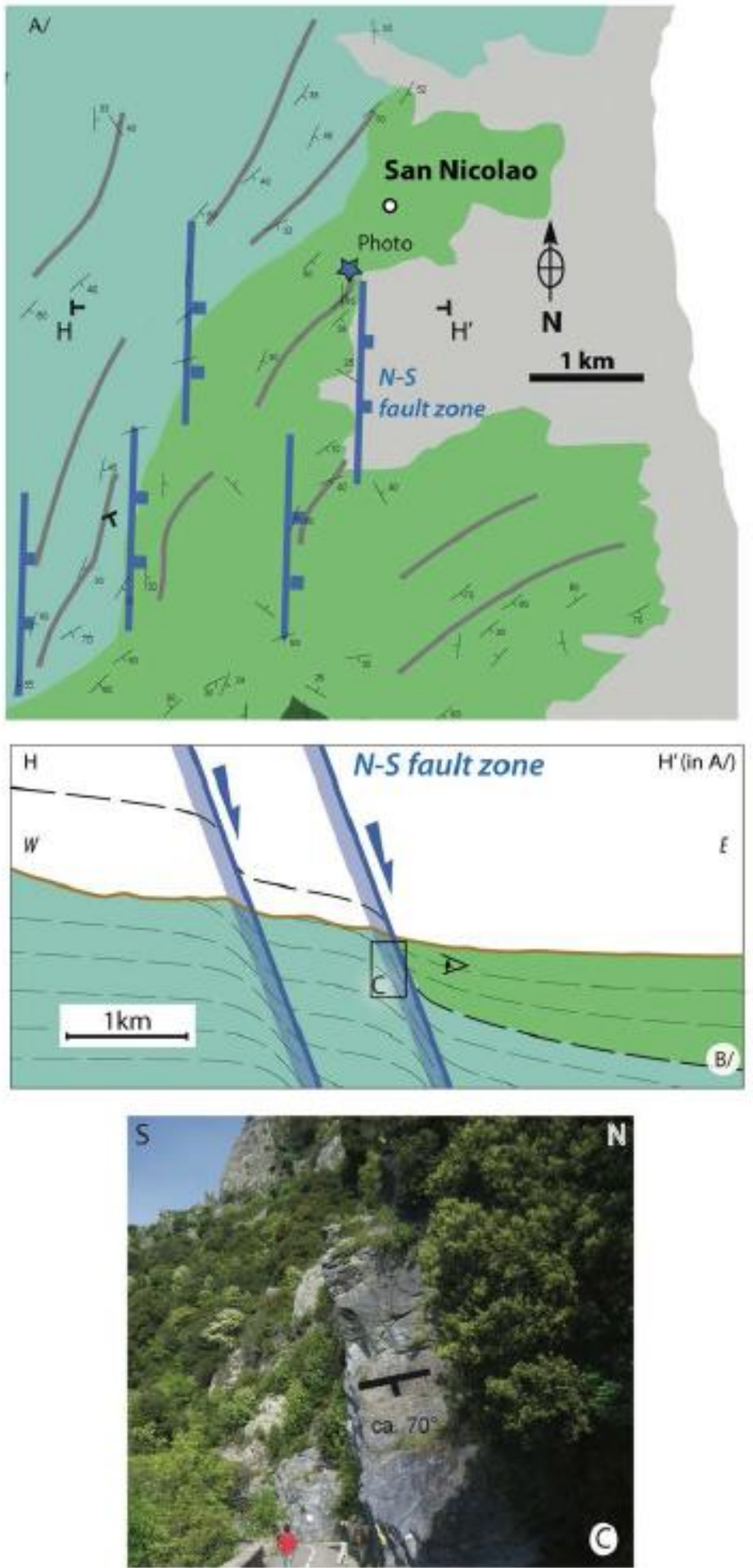

Figure 8/ N-S fault zones in the Schistes Lustrés in the vicinity of San Nicolao (See location in Fig. 3). A/ Detailed structural map illustrating the change in foliation trends. $\mathrm{B} / \mathrm{E}-\mathrm{W}$ crosssection (location $\mathrm{HH}$ ' in $\mathrm{A} /$ ) showing the deformation zone (flexure in light blue) associated with N-S fault zones (see text for further details). C/ outcrop photographs of steeply dipping foliations (location in $B /$ ). 

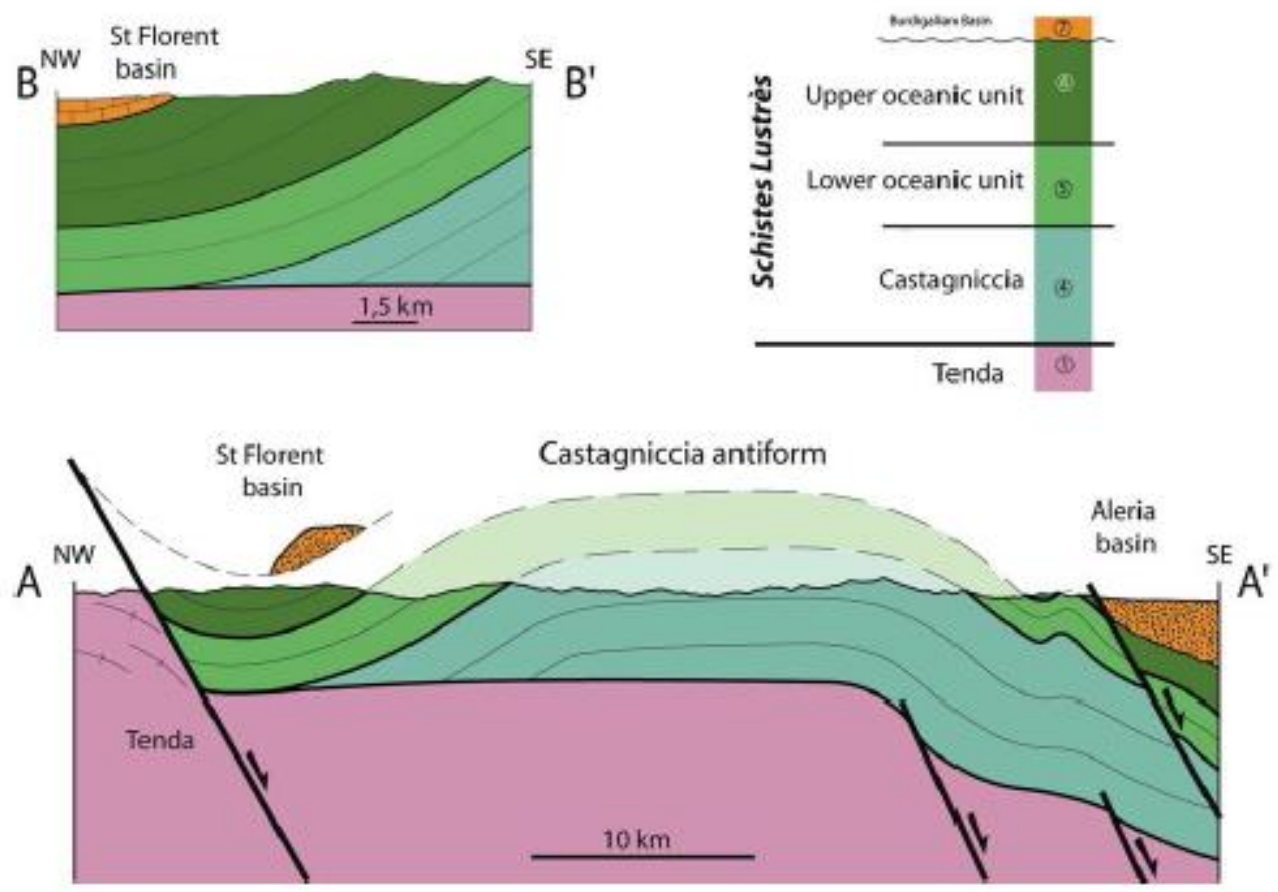

Figure 9/ Simplified geological cross-section of the St Florent basin and its basement (Section BB') and of the Castagniccia anticline (Section AA'). See location of the two sections in Figure 3 

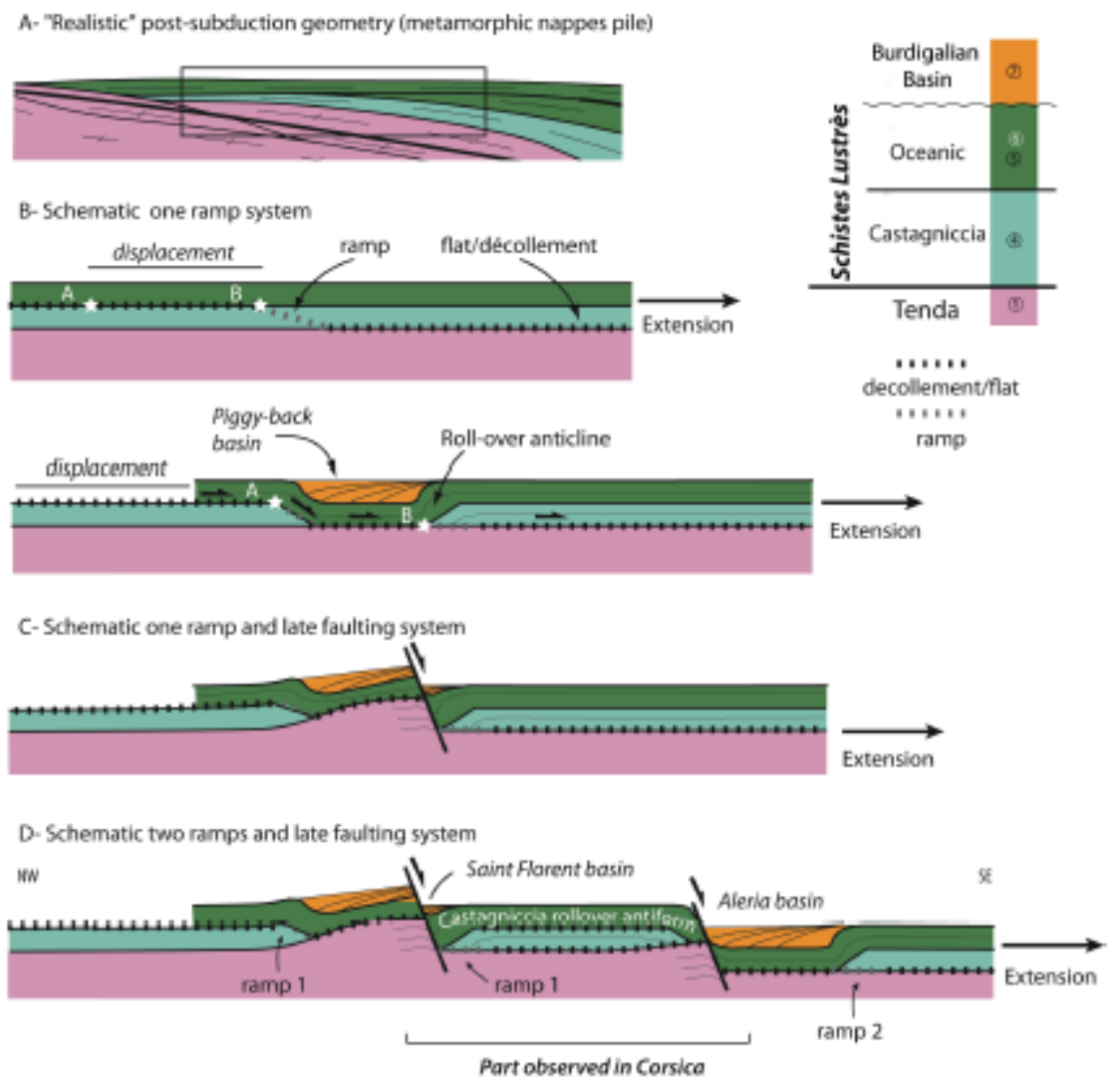

Figure 10/ Simple geometrical two-stage model of a ramp-flat extensional system with location of piggy-back basins. A/ "Realistic" pre-extensional sytem (Alpine nappes pile, redraw from Molli 2008) with location as a rectangle of simplified models shown in B/, C/ and D/, B/ one ramp model with initial (up) and deformed (down) geometry; $\mathrm{C} /$ one ramp model and late normal faulting; $\mathrm{D} /$ two ramp model and late normal faulting; Compare with the complex geometry of cross-section AA' in Fig. 9 


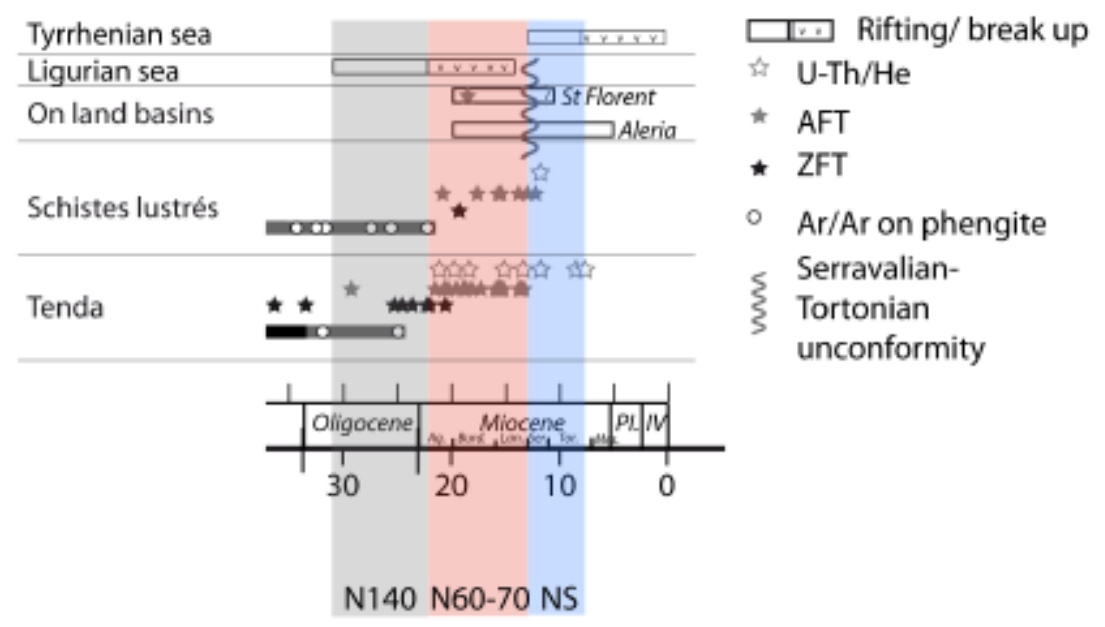

Figure 11/ Ages of the three extensional stages and related regional-scale structures/fault zones (N140 in grey; N60-70 in red; N-S in blue) based on our compilation of ages (see Fig. 2). 


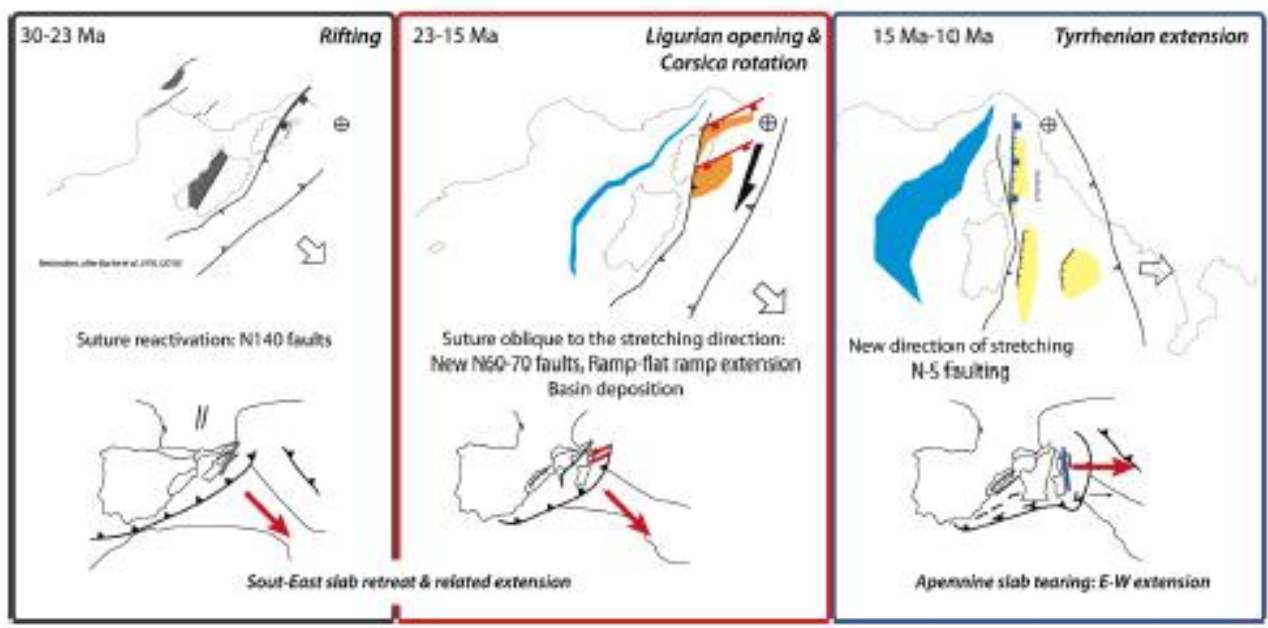

Figure 12/ Geodynamic significance of $\mathrm{N} 140^{\circ}$ ductile fault zones (left), N60 $-70^{\circ}$ ramp-flat extension (middle) and N-S fault zones (right) in the tectonic framework of the central Mediterranean and of the Apennines slab rollback (modified from Faccenna et al., 2004). 


\section{Highlights}

- We evidence three stages of extension in Alpine Corsica

- Oligocene extension accommodated by N140 ${ }^{\circ}$ trending fault zones

- Burdigalian ramp-flat extension controlled by $\mathrm{N} 60^{\circ}-70^{\circ}$ trending fault zones

- Serravalian N-S trending fault zones

- Alpine Corsica has recorded the Apennines slab rollback history 